\title{
Nemajetková újma při ublížení na zdraví a její vyrovnání prospěchem (compensatio lucri cum damno)*
}

\section{Benefit Deduction from Damages for Personal Injury (compensatio lucri cum damno)}

\author{
Ivo Smrž** , Tomáš Doležal ${ }^{* * *}$
}

\begin{abstract}
Abstrakt
Prédmètem článku je problematika vyrovnání újmy prospèchem (compensatio lucri cum damno) v civilním deliktním právu v souvislosti s nábradou nemajetkové újmy prì ubliženi na zdraví, tedy v českém právu s bolestným, nábradou za żtiženi společenskébo uplatnèni a za dalsí nemajetkové ijmy. Nejprve bude v clánku pojednáno obecnè o üskalich souvisejicich s vyrovnáním nemajetkové uijmy na zdravi nabytím prospèchem. Následovat bude rozbor jednotlivých doktrinárnich a judikatornich názorì a kritériú, podle nich ž je mo:̌né relevantni prǒpady posuzovat, včetnè dostupné (nèmecké a rakouské) judikatury. Závèr článku bude vènován typickým skupinám prĭpadu této oblasti v návaznosti na relevantni kritéria pro jejich posuzování.

Klíčová slova

Nábrada škody; újma; vyrovnáni újmy prospèchem.

\section{Abstract}

The article focuses on the tort law concerning the deduction of benefits from damages for personal injury (compensatio lucri cum damno), i.e. in the Czech law in relation to the compensation for pain and suffering, deteriorated social position and other non-pecuniary harm. At first, the article deals in general with problematic aspects associated with benefit deduction from damages for personal injury. This will be followed by an analysis of the various doctrinal and judicial opinions and the criteria according to which the relevant cases could be assessed and solved, including the available (German and Austrian) case law. The conclusion of the article will be aimed at typical groups of cases in connection with the relevant criteria for their assessment.
\end{abstract}

\section{Keywords}

Damages; Personal Injury; Benefits; Deduction.

\section{Úvod - teorie vyrovnání újmy prospěchem}

Problematika vyrovnání újmy prospěchem představuje v teorii i praxi civilního deliktního práva jednu z klíčových otázek, která má významné dopady pro chápání celého systému

Tento článek byl vypracován s podporou GAČR v rámci grantového projektu 20-27258S.

** JUDr. Ivo Smrž, Ph.D., Ústav státu a práva AV ČR, v.v.i. / Institute of State and Law of the CAS, Czech Republic/E-mail:smrz@ilaw.cas.cz

*** Doc. JUDr. Tomáš Doležal, Ph.D., LL.M., Ústav státu a práva AV ČR, v.v.i. / Institute of State and Law of the CAS, Czech Republic / E-mail: tomas.dolezal@ilaw.cas.cz 
náhrady škody. O tom svědčí například velké množství zdrojů dostupných pro německé rakouské anglické $^{3}$ či americké právo ${ }^{4}$. Je tudíž až s podivem, že se v českém právu této problematice doposud nikdo podrobněji nevěnoval ${ }^{5}$, a to přesto, že se jedná o oblast nejen s výrazným teoretickým, ale i praktickým potenciálem. Slovy Richarda Lewise ${ }^{6}$ nejde o hledání odpovědí na otázky „zda“ (nahradit), nýbrž na praktické otázky „kolik“ (nahradit).

V zahraničí bývá tato problematika souhrnně označována latinským výrazem compensatio lucri cum damno. V německy hovořících zemích se užívá rovněž termínu Vorteilsausgleichung $\mathrm{v}$ angloamerickém právu jde mj. o problematiku tzv. collateral benefits. ${ }^{8} \mathrm{~V}$ České republice se většinou používá termínu vyrovnáni újmy prospěchem, ale s ohledem na relativně nízkou frekvenci používání tohoto institutu se nedá hovořit o zavedené terminologii.

Oč v př́padě vyrovnání újmy prospěchem jde? Obecně řečeno, v př́ípadě vyrovnání újmy prospěchem se jedná o situace, $\mathrm{v}$ nichž událost vyvolávající povinnost k náhradě újmy nezpůsobí toliko újmu, nýbrž dá současně vzniknout určitému prospěchu (výhodě, užitku) na straně poškozeného. ${ }^{9}$ Oertmann ${ }^{10}$ ve svém vlivném díle již před více jak sto lety vymezil tuto problematiku jako oprávnění škůdce započíst za určitých předpokladů prospěch, který získal pro poškozeného, proti újmě, již má nahradit.

Klíčová otázka, se kterou se tato oblast práva vypořádává, zní, zda je př́ípustné a obecně vůbec vhodné prospěch nabytý $\mathrm{v}$ důsledku škodní události při stanovení výše újmy zohlednit. Jinak řečeno, zda je zapotřebí prospěch, který poškozený škodní události nabyl, odečíst od celkové náhrady újmy, či poškozenému přiznat nejen celkovou náhradu

1 Pro přehled zdrojů viz např. LANGE, H. a G. SCHIEMANN. Schadensersatz. 3., přepracované vyd. Tübingen: Mohr Siebeck, 2003, s. 486.

2 Viz např. KOZIOL, H. Österreichisches Haftpflichtrecht. Allgemeiner Teil. 3., přepracované vyd. Wien: Manz, 1997, s. 326.

3 LEWIS, R. Deducting Benefits from Damages for Personal Injury. Oxford: Oxford University Press, 2009.

4 Restatement of torts, Restatement Of The Law, Second, Torts $\int 920$.

5 V odborné literatuře lze nalézt, velmi zřídka, statě, které se této problematiky dotýkají, avšak toliko velmi obecně, spíše lze říci přehledově. Zmínit je možné pasáž v monografii Štefana Lubyho Prevencia a zodpovednost' v občianskom práve čítající čtyři strany: LUBY, Š. Prevencia a zodpovednost' v občianskom práve. Bratislava: Vydavatel'stvo Slovenskej akadémie vied, 1958, s. 353-357; Či obdobně podkapitolu Filipa Melzera v komentáři k občanskému zákoníku čítající šest stran: MELZER, F., P. TÉGL a kol. Občanský zákoník - velký komentár. Svažek IX. 』 2894-3081. Praha: Leges, 2018, s. 943 a násl.

6 LEWIS, R. Deducting Benefits from Damages for Personal Injury. Oxford: Oxford University Press, 2009, s. vii.

7 Z rakouské doktríny viz např. KOZIOL, H. Österreichisches Haftpflichtrecht. Allgemeiner Teil. 3., přepracované vyd. Wien: Manz, 1997, s. 326 a násl.; Z německé pak LANGE, H. a G. SCHIEMANN. Schadensersatz. 3., přepracované vyd. Tübingen: Mohr Siebeck, 2003, s. 486 a násl.

8 Viz např. The Law on Damages. Consultation Paper, CP 9/07, 04/05/2007, s. 44 a násl. Dostupné z: https://webarchive.nationalarchives.gov.uk/+/http:/www.dca.gov.uk/consult/damages/cp0907.pdf

9 Viz např. LANGE, H. a G. SCHIEMANN. Schadensersatæ. 3., přepracované vyd. Tübingen: Mohr Siebeck, 2003, s. 486.

10 OERTMANN, P. Die Vorteilsausgleichung beim Schadensersatzanspruch im römischen und deutschen bürgerlichen Rechte. Reprint 2018 (1. April 1901). Berlin: De Gruyter, 2018, s. 12. 
újmy, ale také mu ponechat nabytý prospěch. A to primárně z důvodu, aby se poškozený skrze poskytnutou náhradu a prospěch bezdůvodně neobohatil a současně aby škůdce nenahradil méně, než kolik činí skutečně způsobená újma.

Položenou otázku není vždy snadné zodpovědět. Nahlédneme-li do českého právního rádu, zjistíme, že obecně použitelné pravidlo neobsahuje, i když na některých místech se zohledněním prospěchu počítá, viz např. oblast explicitně zakotvených regresních nároků zdravotních pojišt'oven ${ }^{11}$ či zákonnou cesi zakotvenou v ustanovení \2820 OZ ${ }^{12}$.

A není to ostatně nic neobvyklého, při pohledu kupř. do německého práva si byl zákonodárce při tvorbě německého občanského zákoníku ${ }^{13}$ nemožnosti podchycení této problematiky univerzálním zákonným ustanovením vědom, v důvodové zprávě (materiálech) k BGB proto uvádí, že její řešení ponechal doktríně a rozhodovací praxi soudů. Finální verdikt, zda bude třeba konkrétní újmu vyvážit určitým prospěchem, nelze uspokojivě řešit apriorně pro všechny př́pady, jelikož tento verdikt vyžaduje zohlednění komplexu pravidel, zejména posouzení toho, co je třeba rozumět újmou v daném konkrétním prrípadě. ${ }^{14}$ Inherentní této problematice je její závislost na hodnotovém úsudku (wertende Betrachtung, value judgment). Při řešení jednotlivých případů (zohlednění/odmítnutí prospěchu) je třeba vzít v potaz naprŕklad funkce deliktního práva, pravidla způsobu výpočtu výše nahrazované újmy, přiměřenost a spravedlnost náhrady atd. Trefně shrnuje Gottfried Schiemann ${ }^{15}$, že vyrovnání újmy prospěchem je branou pro užití hodnot v jinak čistě početním a technicky chápaném právu náhrady újmy.

Např́klad německé právo se snaží koncepčně vypořádat s problematikou vyrovnání újmy prospěchem již více jak sto let. Nárůst zájmu nastal na přelomu devatenáctého a dvacátého století. Jak uvádí Kuhn ${ }^{16}$, zpočátku se snaha doktríny i judikatury nesla ve znamení hledání univerzálního pravidla, což ale bylo marné. Jakýkoliv komplexní princip byl bud' vystavěn na řadě výjimek, nebo naopak tak široce (neurčitě) formulován, že v důsledku trpěl absencí kýžené vypovídací hodnoty. Zmiňme např́iklad Thieleho ${ }^{17}$ a jeho „,nerozlučné spojení“ (,unlösbare Zusammenhang“) či Cantzlera ${ }^{18}$ a započtení prospěchu, který

11 Podle ustanovení \55 zákona č. 48/1997 Sb., o veřejném zdravotním pojištění a o změně a doplnění některých souvisejících zákonů, ve znění pozdějších předpisů. Dále jen „ZVZP“.

12 Zákon č. 89/2012 Sb., občanský zákoník, ve znění pozdějších předpisů. Dále jen „OZ“.

13 Dále jen „BGB“. Dostupné z: https://www.gesetze-im-internet.de

14 MUGDAN, B. Die gesammten Materialien zum Bürgerlichen Gesetzbuch für das Deutsche Reich. II. Band. Berlin: R.v. Decker`s Verlag, 1899, s. 10.

15 SCHIEMANN, G. Argumente und Prinzipien bei der Fortbildung des Schadensrechts. München: C. H. Beck, 1981, s. 122.

16 KUHN, R. Die Anrechnung von Vorteilen im Haftpfichtrecht. Bern-Stuttgart: Paul Haupt Bern und Stuttgart, 1987, s. 2 a násl.

17 THIELE, W. Gedanken zur Vorteilsausgleichung. Archiv für die civilistische Praxis, 1967, roč. 167, č. 3.

18 CANTZLER, K. Die Vorteilsausgleichung beim Schadensersatzanspruch. Archiv für die civilistische Praxis, 1957 , roč. 156 , č. 1. 
znamená podporu porušené smluvní povinnosti nebo zasaženého právního statku. O konkrétnější pravidla se jistě jedná, avšak jak posoudit, zda mezi prospěchem a újmou existuje nerozlučné spojení, anebo prospěch podporuje zasažené hodnoty, bohužel jinak než kazuisticky nejde. Mladší doktrína a současně i rozhodovací praxe soudů staví na tvorbě skupin prípadů (Fallgruppen) s obdobnými rysy rozhodnými pro jejich posouzení. Jedná se tedy o snahu ještě určitého zobecňování kazuistiky. ${ }^{19}$

Předmětem předkládaného článku není oblast problematiky vyrovnání újmy prospěchem jako celek, nýbrž její relativně ucelená část týkající se specifik vyrovnání nemajetkové újmy při ublížení na zdraví nabytým prospěchem. Nebude se tedy jednat o oblast majetkové újmy, pro niž jsou kritéria pro posuzování jednotlivých prrípadů primárně vytvořena, ale o oblast újem ideálních. S tím úzce souvisejí problematické aspekty vyrovnání nemajetkové újmy nabytým prospěchem odvislé od povahy nemajetkové újmy jako takové, se kterými je třeba se rovněž vypořádat.

Zatímco u vyrovnání majetkové újmy jde o rozhodování, zda zohlednit, či nezohlednit výhody v podobě materiálních statků, jako např́klad různé dávky sociálního zabezpečení, pojistná plnění, finanční dary apod., v prŕípadě vyrovnání nemajetkové újmy se do popředí dostávají hodnoty ideální, což implikuje obtíže spojené s jejich vyčíslováním v penězích.

Tyto teze lze demonstrovat na př́padu z české soudní praxe. Ústavní soud řešil spor ${ }^{20}$, v němž šlo o zohlednění př́spěvku na péči při náhradě nákladů na léčení (nákladů vynaložených na zajištění pomoci při základních životních úkonech a na zajištění chodu domácnosti). Ústavní soud dospěl k závěru, že je třeba prŕspěvek od náhrady nákladů odečíst. Bude-li např́iklad náklad na léčení činit 20000 Kč a příspěvek na péči 12000 Kč, pak bude škůdce povinen nahradit majetkovou škodu v rozsahu 20000 Kč minus $12000 \mathrm{Kč}$, tedy 8000 Kč. Pekuniární vyčíslení výhody a její zohlednění oproti nevýhodě (majetkové újmě) zde nečiní problém.

Oproti tomu lze předestrút př́pady projednávané rakouskými soudy a tam uvedené nemajetkové výhody, jež žalovaní požadovali zohlednit (odečíst) od náhrady nemajetkové újmy v podobě bolestného, tedy od náhrady za způsobenou nemajetkovou újmu na zdraví. Jednalo se např́klad o bolesti „ušetřené“ ${ }^{\text {“21 }}$ neprovedením operace ${ }^{22}$ či bolesti „ušetřené“ neprovedením porodnického výkonu $\mathrm{v}$ podobě císařského řezu ${ }^{23}$ či konečně o vyléčení nemoci. ${ }^{24}$ Obtíže spojené s vyčíslováním těchto „výhod“ v penězích jsou naprosto zřejmé.

\footnotetext{
19 Uved'me autory jako Thüssing, Kuhn, Lange a Schiemann či Koziol.

20 Usnesení Ústavního soudu ze dne 28.1.2020, sp. zn. III. ÚS 4194/18.

21 „Ersparte Schmerzen“.

22 Rozhodnutí OGH ze dne 13.1.2004, 5 Ob 242/03d. Dostupné z: https://www.ris.bka.gvat

23 Rozhodnutí OGH ze dne 10.6.2008, 4 Ob 78/08m. Dostupné z: https://www.ris.bka.gv.at

24 Rozhodnutí OGH ze dne 27.5.2004, 6 Ob 54/04s. Dostupné z: https://www.ris.bka.gv.at
} 
Problémy související s pekuniárním vyčíslením ideálních výhod nejsou jedinými, zmínit lze dále kongruenci majetkových a nemajetkových výhod s ideální nevýhodou (újmou), aplikaci neurčitých právních pojmů jako přiměřenost, spravedlnost, rovnost, dále nutnost stanovení určitého minimálního prahu, od něhož je třeba výhody zohledňovat ${ }^{25}$ a zda vůbec určitou výhodu zohlednit ${ }^{26}$, či konečně obavy z nedostatečného odčinění nemajetkové újmy při zohlednění některých výhod.

Cílem článku je proto zanalyzovat a vypořádat se se specifiky vyrovnání nemajetkové újmy při ublížení na zdraví nabytým (ideálním) prospěchem. Nejprve budou uvedeny argumenty svědčící pro a proti zohlednění výhod při odčinění nemajetkových újem na zdraví. Následovat bude rozbor jednotlivých doktrinárních a judikatorních názorů a kritérií, podle nichž je možné relevantní př́pady zohledňování výhod posuzovat, včetně dostupné (německé a rakouské) judikatury. Závěr článku bude věnován shrnutí relevantních kritérií v návaznosti na př́slušné skupiny případů (tzv. „Fallgruppen“), a jejich využití v českém právu, které koncepčně tuto problematiku dosud nepostihuje.

V článku je ve značné míře pracováno s německou a rakouskou doktrínou i judikaturou, jak lze seznat již z úvodních pasáží. Je tomu tak nejen proto, že se při tvorbě OZ a právní úpravy deliktního práva zákonodárce oběma jurisdikcemi inspiroval a mnoho tam zakotvených pravidel, i když s vybranými změnami, převzal (viz např. ustanovení \2910 OZ ve srovnání s ustanovením \823 BGB), ale také z důvodu, že se tyto právní rády z koncepčního hlediska problematikou vyrovnání újmy prospěchem zabývají dlouhodobě, což umožňuje robustní a provázanou doktrinární diskusi, včetně autoritativního výkladu ze strany soudní praxe. V neposlední řadě je třeba rovněž zmínit kulturní i geografickou blízkost a s tím související vliv na formování práva českého.

\section{Vyrovnání újmy prospěchem při odčiňování nemajetkové újmy při ublížení na zdraví?}

Na mnoha místech v rámci německé i rakouské doktríny se setkáme s názorem, že v př́ipadě vyrovnání nemajetkové újmy prospěchem při ublížení na zdraví o aplikaci teorie vyrovnání újmy prospěchem (Vorteilsausgleichung) v jejím původním smyslu vůbec nejde. Lange s Schiemannem ${ }^{27}$ například poukazují na skutečnost, že bolesti nelze štěpit (jako v případě majetku) ${ }^{28}$, jednoduše není možné nejprve vyčíslit výši bolestného za způsobenou újmu a následně ryze matematicky odečítat peněžní hodnotu té které nemajetkové výhody.

25 Obdobně viz např. SMRŽ, I. Duševní újmy na zdraví a jejich odčiňování v civilním právu. Časopis zdravotnického práva a bioetiky, 2019, roč. 9, č. 2, s. 23.

26 Typicky u výhod v podobě narození dítěte v tzv. „wrongful birth“/,wrongful life“př́ípadech.

27 LANGE, H. a G. SCHIEMANN. Schadensersatz. 3., přepracované vyd. Tübingen: Mohr Siebeck, 2003, s. 497.

28 THÜSING, G. Wertende Schadensberechnung. München: C. H. Beck, 2001, s. 37. 
I přesto v rámci rakouské i německé doktríny převažuje názor, že je třeba výhody oproti způsobené nemajetkové újmě (bolestnému) zohledňovat ${ }^{29}$, i když nikoliv př́sně podle teorie vyrovnání újmy prospěchem. ${ }^{30}$ Například německá doktrína podpořená judikaturou BGH pro toto tvrzení vychází z dikce ustanovení \ 253 odst. 2 BGB ${ }^{31}$, podle něhož může být za nemajetkovou újmu při ublížení na zdraví požadováno spravedlivé odškodněni $\mathrm{v}$ penězích. A právě odkaz na spravedlnost odškodnění znamená zohlednění všech v potaz přicházejících okolností případu, kterými jsou zřetelně i z protiprávního jednání vzniklé výhody. ${ }^{32} \mathrm{~V}$ českém právu v této souvislosti srov. druhou větu ustanovení \2958 OZ ${ }^{33}$, navazující odškodnění za nemajetkovou újmu při ublížení na zdraví na zásady slušnosti, které směřují k zohlednění všech okolností jednotlivého př́padu. ${ }^{34}$

Pouhý odkaz na spravedlnost v rámci peněžitého odškodnění ale nevyřeší otázku, jaké, a v jaké míře, výhody vzniklé protiprávním jednáním zohlednit; i výše bolestného jako takového (při absenci výhod) vyžaduje odůvodnění, které neobsahuje pouze prázdné fráze, ale je věcné a pro účastníky řízení srozumitelné. Spravedlnostní úvahy v rámci odůvodnění musí vždy být důkladné a vztažené ke konkrétnímu případu. ${ }^{35} \mathrm{U}$ vyrovnání nemajetkových výhod prospěchem to platí dvojnásob, i proto je třeba relevantní doktrinární a judikatorní kritéria teorie vyrovnání újmy prospěchem vztáhnout i na tuto oblast. Přestože se většina názorů kloní k zohlednění výhod při odčiňování nemajetkových újem způsobených ublížením na zdraví, objevují se i argumenty proti takovému zohlednění.

29 Podrobněji viz dále.

30 DANZL, K. H., K. GUTIÉRREZ-LOBOS a O. F. MÜLLER. Das Schmerzengeld in medizinischer und juristischer Sicht. 9. vyd. Wien: Manz, 2008, s. 279; KERSCHNER, F. Schmerzengeld. Kommentar und Judikatur. Verlag Österreich: Wien, 2013, s. 133; ERM, D. Vorteilsanrechnung beim Schmerzensgeld - ein Beitrag zur Fortentwicklung des Schadens(ersatz)rechts. Karlsruhe: Verlag Versicherungswirtschaft GmbH, 2013, s. 237; PLETZER, R. Vorteilsausgleich beim Schmerzengeld? Juristische Blätter, 2007, roč. 129, č. 7, s. 423; SCHIEMANN, G. In: HUBER, Ch., D. JAEGER a J. LUCKEY. Festschrift für Lothar Jaeger zum 75. Geburtstag. Luchterhand Verlag, 2014, s. 413.

31 „Ist wegen einer Verletzung des Körpers, der Gesundheit, der Freiheit oder der sexuellen Selbstbestimmung Schadensersatz zu leisten, kann auch wegen des Schadens, der nicht Vermögensschaden ist, eine billige Entschädigung in Geld gefordert werden." [Má-li být v důsledku zásahu na těle, zdraví, svobodě nebo sexuálním sebeurčení poskytnuta náhrada újmy, může být i za újmu, která není újmou majetkovou, požadováno spravedlivé odškodnění v penězích.]

32 Viz rozhodnutí BGH ze dne 6.7.1955, GSZ 1/55: „,Bei der Festsetzung dieser billigen Entschädigung dürfen grundsätəlich alle in Betracht kommenden Umstände des Falles berücksichtigt werden..." [Při stanovení tohoto spravedlivého odškodnění mohou být v zásadě zohledněny všechny v úvahu připadající okolnosti př́ipadu...]. Dostupné z: https://dejure.org

33 Zákon č. 89/2012 Sb., občanský zákoník, ve znění pozdějších předpisů. Dále jen „OZ““

34 Podrobněji viz DOLEŽAL, T. In: MELZER, F., P. TÉGL a kol. Občanská zákoník - velký komentár. Svazek IX. 』2894_3081. Praha: Leges, 2018, s. 998.

35 SCHIEMANN, G. In: HUBER, Ch., D. JAEGER a J. LUCKEY. Festschrift für Lothar Jaeger zum 75. Geburtstag. Luchterhand Verlag, 2014, s. 412. 
První tkví v zásadní nevyčíslitelnosti nemajetkových výhod, jinak řečeno, v obtížnosti (objektivní nemožnosti) jejich převodu na peněžní hodnotu, což může vést k nejasným, netransparentním a paušálním soudům při zvažování všech faktorů determinujících výši odškodnění (bolestného). ${ }^{36} \mathrm{~S}$ tím úzce souvisí i obava $\mathrm{z}$ nedostatečného odškodnění (Unterkompensation) způsobené nemajetkové újmy. Pokud bude nemajetková výhoda ohodnocena př́liš vysoko, dojde na straně poškozeného k odečtení více, než skutečně činí újma. ${ }^{37}$ Proti předestřeným námitkám lze primárně uvést, že i ideální nevýhody jsou zásadně v penězích nevyčíslitelné, včetně zdraví, viz odkaz na římskoprávní zásadu „,liberum corpus nullam recipit aestimationem “ ${ }^{38}$ Přesto moderní právní řády vycházejí z možnosti kompenzovat újmu na zdraví penězi, čímž nepřímo prripouštějí její vyčíslitelnost. Avšak kompenzace tohoto typu újmy a její pravidla jsou pouhým normativním konstruktem, který vznikl $\mathrm{v}$ důsledku nedostatku jiných možností odškodnění, a to prostřednictvím pořizení jiných výhod. ${ }^{39} \mathrm{~S}$ ohledem na zásadu rovnosti není možné odmítat „vyčísleni““ nemajetkových výhod a současně připustit opak u nemajetkových nevýhod, tedy nemajetkových újem. ${ }^{40}$ Odmítnutí vyrovnání nemajetkové újmy prospěchem poukazem na obavu z nedostatečného odškodnění může být relativizováno excesem na druhé straně, a to nadměrným odškodněním. ${ }^{41}$ Bude-li paušálně jakákoliv nemajetková výhoda při stanovení výše bolestného pominuta, může poškozený obdržet v konečném důsledku nejen bolestné jako takové, ale také nemajetkovou výhodu. Obě krajní situace zřetelně nekonvenují kompenzační funkci náhrady nemajetkové újmy a nelze jimi odůvodňovat akceptaci či odmítnutí vyrovnání újmy prospěchem.

Další protiargument spočívá v potírání preventivní, resp. represivní funkce civilního deliktního práva a konkrétně i náhrady za způsobenou nemajetkovou újmu. Dojde-li k nespravedlivému zohlednění výhody při stanovení výše bolestného na straně škůdce, bude takový postup odporovat preventivním, resp. represivním prvkům. Motivace škůdce nepůsobit negativně na (ideálnî) statky bude patrně snížena.

Pletzer ${ }^{42}$ poměrně jednoduše kontruje. Dojede-li k zohlednění kongruentních ideálních výhod, zůstanou preventivní i represivní prvky odčinění zachovány, jelikož, za předpokladu zachování celistvosti bolestivého stavu, působí výsledná výše bolestného na škůdce obsahující jak negativní, tak i pozitivní faktory, per se preventivně i represivně.

36 ERM, D. Vorteilsanrechnung beim Schmerzensgeld - ein Beitrag zur Fortentwicklung des Schadens(ersatz)rechts. Karlsruhe: Verlag Versicherungswirtschaft GmbH, 2013, s. 231.

37 THÜSING, G. Wertende Schadensberechnung. München: C. H. Beck, 2001, s. 459.

38 Gaius D. 9,3,7.

39 DOLEŽAL, T. Jak odškodňovat nemateriální újmy na zdraví? Principy a východiska. Časopis zdravotnického práva a bioetiky, 2016, roč. 6, č. 1, s. 45.

40 ERM, D. Vorteilsanrechnung beim Schmerzensgeld - ein Beitrag zur Fortentwicklung des Schadens(ersatz)rechts. Karlsruhe: Verlag Versicherungswirtschaft GmbH, 2013, s. 243.

41 PLETZER, R. Vorteilsausgleich beim Schmerzengeld? Juristische Blätter, 2007, roč. 129, č. 7, s. 419.

42 PLETZER, R. Vorteilsausgleich beim Schmerzengeld? Juristische Blätter, 2007, roč. 129, č. 7, s. 422. 
Lze shrnout, že i v prŕpadě nemajetkové újmy při ublížení na zdraví je třeba nemajetkové výhody oproti způsobené nemajetkové újmě (bolestnému) zohledňovat, dalo by se říci, přiměřeně podle teorie vyrovnání újmy prospěchem. Následující pododdíly jsou proto zaměřny na relevantní doktrinární a judikatorní kritéria pro posuzování těchto př́padů.

\section{Reprezentativní judikatura př́ípadů vyrovnání bolestného nemajetkovými výhodami}

$\mathrm{V}$ rámci tohoto pododdílu budou představeny vybrané ${ }^{43}$ prrípady z německé a rakouské judikatury, které se problematikou vyrovnání bolestného výhodami zabývaly. Judikatura je tvořena především v oblasti zdravotnického práva, konkrétně v rámci vztahu lékaře a pacienta, jelikož je zde obecně pravděpodobné, že postup lékaře, i když protiprávní, dá na straně pacienta vzniknout nemajetkové výhodě, například v podobě již zmíněných „ušetřených“ bolestí nebo zlepšení zdravotního stavu eliminací určitého onemocnění.

Před nastíněním jednotlivých prŕpadů je důležité upozornit na dvě důležitá specifika německého i rakouského práva. Prvé spočívá ve skutečnosti, že nárok na náhradu nemajetkové újmy na zdraví je celistvý (jde o tzv. „Schmeržensgeld“", bolestné) ${ }^{44}$, netvoří jej jednotlivé dílčí nároky jako v právu českém dle ustanovení \2958 OZ ${ }^{45}$ - bolestné, náhrada za ztížení společenského uplatnění a za další nemajetkové újmy. Druhé specifikum tkví ve skutečnosti, že jakýkoliv zákrok lékaře bez informovaného souhlasu pacienta naplní př́slušnou skutkovou podstatu povinnosti k náhradě újmy na zdraví, přičemž tím pacientovi vznikne právo na bolestné. ${ }^{46}$

\section{$2.1 \mathrm{OGH} 10 \mathrm{Ob} 209 / 02 \mathrm{~m}^{47}$}

V posuzovaném př́padě šlo o medicínsko-právní spor mezi zubním lékařem (žalovaným) a jeho pacientkou jako žalobkyní. Pacientka byla dlouhodobě v péči žalovaného,

43 Soudní rozhodnutí byla vybrána zejména s ohledem na skutečnost, že s nimi rakouská i německá doktrína pravidelně pracuje, přičemž současně významným způsobem reflektují zkoumanou problematiku. Rovněž se jedná o rozhodnutí nejvy̌šších soudních instancí, která mají potenciál sjednocovat judikaturu soudů nižších stupňủ, a tudíž i formovat právní názory na jednotlivé príípady vyrovnání újmy prospěchem.

44 Viz ustanovení 2253 odst. 2 BGB a $\$ 1325$ rakouského občanského zákoníku (dále jen „ABGB“). Dostupné z: https://www.ris.bka.gv.at; GRÜNEBERG, Ch. In: PALANDT, O. (Hrsg.). Bürgerliches Gesetz̧buch. 78. , přepracované vyd. München: C. H. Beck, 2019, s. 328; HARRER, F. In: SCHWIMANN, M. $A B G B$ Praxiskommentar. Band 6. IJ 1293-1502 ABGB. 3., přepracované vyd. Wien: LexisNexis ARD Orac, 2006, s. 437.

45 Což potvrdila judikatura Nejvyššího soudu: usnesení Nejvyššího soudu ze dne 1.11. 2017, sp. zn. 25 Cdo $2245 / 2017$.

46 SPRAU, H. In: PALANDT, O. (Hrsg.). Bürgerliches Gesetz̧buch. 78., přepracované vyd. München: C. H. Beck, 2019, s. 1486; HARRER, F. In: SCHWIMANN, M. ABGB Praxiskommentar. Band 6. $\iint$ 1293-1502 ABGB. 3., prrepracované vyd. Wien: LexisNexis ARD Orac, 2006, s. 172.

47 Rozhodnutí OGH ze dne 18.7.2002, 10 Ob 209/02m. Dostupné z: https://www.ris.bka.gv.at 
přičemž byla třeba zcela zásadní renovace jejího chrupu. Zubní lékař provedl mnoho zákroků (ošetření kořenových kanálků, nasazení korunek či můstků atd.). Pacientka po lékaři požadovala mj. bolestné, a to za nedostatečné poučení před samotnými zákroky spočívající v absenci informací o alternativách a rizicích zákroků, zejména co do možnosti hnisání po ošetření kořenových kanálků. Žalovaný lékař proti nároku na bolestné požadoval započíst (zohlednit) veškeré „ušetřené“ bolesti pacientky spojené s tvrzeným alternativním zákrokem - zrrízením protézy celého chrupu.

Soud v rozhodnutí poměrně detailně rozebral teorii vyrovnání újmy prospěchem, zhusta prritom odkazoval na doktrínu (např. Koziol, Harrer, Danzl, Karner, Reischauer):

- teorie vyrovnání újmy prospěchem primárně směřuje na materiální škodu, soud při tom argumentoval mimo jiné účelem civilního deliktního práva (vyrovnávací funkcî) ${ }^{48}$;

- soudy již zdůraznily, že zohlednění výhody musí odpovídat smyslu civilního deliktního práva a současně nesmí docházet k nespravedlivému zvýhodnění škůdce ${ }^{49}$;

- funkce bolestného spočívá v odškodnění způsobené nemajetkové újmy a má sloužit $\mathrm{k}$,opatřeni““ si radosti ze života a překonání pocitů nelibosti; ${ }^{50}$

- doktrína i judikatura započtení majetkové výhody proti nemajetkové nevýhodě neuznává. ${ }^{51}$

Po teoretické pasáži následovalo samotné posouzení věci, avšak nikoliv věcně ve vztahu k problematice vyrovnání nemajetkové újmy prospěchem. Soud totiž odmítnul skutkové tvrzení žalovaného lékaře, že alternativním zákrokem bylo zhotovení úplné zubní náhrady zahrnující i extrakci všech zubů. Podle soudu byla alternativou pouze částečná

48 „Der Zweck der Ersatzpflicht eines allfälligen Haftpflichtigen ist es, den im Vermögen des Geschädigten entstandenen Schaden auszugleichen. Daraus ist ableitbar, dass dem Geschädigten der gesamte ihm entstandene Schaden zu ersetzen ist. Da aber andererseits eben nur der entstandene Schaden ausgeglichen werden soll, sind grundsätzlich auch alle Vorteile in Betracht zu ziehen und vom Schaden abzurechnen. " [Účel povinnosti odškodnit újmu osobou zavázanou k náhradě spočívá ve vyrovnání újmy vzniklé v majetku poškozeného. Z toho lze dovodit, že poškozenému má být nahrazena celá mu vzniklá újma. Ale vzhledem k tomu, že má být odškodněna pouze vzniklá újma, musí být vzaty v potaz všechny výhody a tyto od újmy odečteny.]

49 „In der Rechtsprechung wird auch betont, dass die Anrechnung eines Vorteils dem Zweck des Schadenersatzes entsprechen muss und nicht qu einer unbilligen Entlastung des Schädigers führen darf." [V judikatuře je také zdůrazňováno, že započtení výhody musí odpovídat účelu náhrady škody a nesmí vést $\mathrm{k}$ nespravedlivému zproštění škůdce nahradit škodu.]

50 „Das Schmerzengeld ist kein Ersatz für Vermögensschäden, sondern eine Entschädigung für einen ideellen (immateriellen) Schaden. Es soll dem Verletzten einen Ausgleich für erlittene Schmerzen und entgangene Lebensfreude bieten und dadurch zur Überwindung seiner Unlustgefüble beitragen." [Bolestné není náhradou majetkové újmy, ale odškodněním imateriální (nemajetkové) újmy. Bolestné by mělo poškozenému poskytnout vyrovnání za vytrpěné bolesti a ušlou radost ze života a tím přispět k překonání jeho pocitů nelibosti.]

51 „Es ist daber in Lehre und Rechtsprechung herrschende Auffassung, dass eine Ersparnisanrechnung als Vermögensvorteil nur gegenüber einem Vermögensschaden erfolgen kann und daber gegenüber dem Schmeržengeld als Entschädigung für einen immateriellen Schaden die Anrechnung eines Vermögensvorteiles nicht stattzufinden hat." Jje tedy v doktríně i judikatuře panujícím názorem, že zohlednit lze ušetřené náklady jako majetkový prospěch pouze vůči majetkové újmě, a proto vůči bolestnému, jako prostředku k odčinění nemajetkové újmy, nemůže být provedeno započtení majetkového prospěchu.] 
protéza, tudíž neexistuje výhoda, která by se dala zohlednit proti požadovanému bolestnému. Nejvyšší soud se tedy obecně k možnosti zápočtu nemajetkových výhod proti bolestnému nevyjádřil.

\subsection{OGH 5 Ob $242 / 03 d^{52}$}

Skutkově se jednalo o žalobu pacientky na zdravotnické zařŕzení kvůli chybnému medicínskému postupu spočivajícímu v opožděné diagnóze a na to navázaném opominutí včasného operačního zákroku, v důsledku čehož došlo u pacientky ke ztrátě hybnosti prstů (tzv. ztuhlý palec). Proti nároku žalobkyně na bolestné požadovalo zdravotnické zařízení započíst nemajetkovou výhodu - ušetření bolesti z včas neprovedené operace, která by byla provedena, nebýt vadné (opožděné) diagnózy.

Soud obdobně jako v př́padě 10 Ob 209/02m zrekapituloval některé aspekty teorie vyrovnání újmy prospěchem, přičemž dodal, že při posuzování těchto př́padů je třeba, aby škodní událost byla příčinou jak způsobené nevýhody (újmy), tak i výhody. ${ }^{53}$

Požadavek kauzality vyložil Nejvyšší soud ve vztahu ke konkrétním okolnostem tohoto sporu v tom smyslu, že v případě újem na zdraví jde o výhodu v podobě ušetření operačního zákroku, pokud je zdravotní stav pacienta po chybném postupu lékaře srovnatelný s (hypotetickým) stavem, kdy k žádné chybě v péči nedošlo. Jelikož v posuzovaném př́padě nešlo o dva srovnatelné stavy (hybnost palce kontra ztráta hybnosti palce), soud zohlednění výhody odmítnul. ${ }^{54}$

52 Rozhodnutí OGH ze dne 13.1.2004, 5 Ob 242/03d. Dostupné z: https://www.ris.bka.gv.at

53 „Voraussetzung für eine Vorteilsausgleichung ist die Kausalität des haftbar machenden Ereignisses für den Nachteil und einen entstandenen Vorteil." "Předpokladem pro vyrovnání újmy prospěchem je, že událost, jež vedla ke vzniku odpovědnosti, byla příčinnou vzniku jak nevýhody (újmy), tak současně i výhody.]

54 „Wie bereits oben dargelegt, ist Voraussetzung für einen Vorteilsausgleich, dass aus demselben schädigenden Ereignis ein Schaden und ein Vorteil für den Geschädigten entstanden ist. Damit überhaupt im Gesundheitsbereich - wie hier bei einem Behandlungsfehler - von einem Vorteil durch Ersparen von operativen Eingriffen - und damit von Schmerzzuständen - gesprochen werden kann, müsste jedenfalls trotz. Feblbehandlung ein vergleichbarer körperlicher Zustand wie obne Feblbehandlung erzielt worden sein. Das heißt, ein Vorteilsausgleich ,erlittener' Schmerzen gegen ,ersparte'Schmerz̧en kann überhaupt nur dann in Betracht kommen, wenn bei der Beurteilung der, Vor-und Nachteile‘ in Form von Schmerzzuständen von zwei vergleichbaren körperlichen Zuständen ausgegangen werden kann (etwa: mit und ohne Fehlbehandlung ein steifer Daumen oder ein bewegungseingeschränkter Daumen). Nur in dem Fall könnte geprüft werden, ob bei dem, durch das schädigende Ereignis verursachten ,Endzustand" (wie bei Vermögensschäden) auch anrechenbare ,Vorteile" entstanden sind. Dies ist hier aber gerade nicht der Fall." JJak bylo uvedeno shora, je předpokladem pro vyrovnání újmy prospěchem skutečnost, že újma a výhoda poškozeného vznikly ze shodné škodní události. Proto, aby v oblasti zásahů do zdraví - jako zde při chybném lékařském postupu - bylo možno hovořit o výhodě vzniklé v důsledku ušetřených operačních zákroků, a tím i o bolestivých stavech, by musel být navzdory chybnému zákroku docílen srovnatelný tělesný stav jako bez chybného zákroku. To znamená, že vyrovnání „vytrpěných“ bolestí proti „ušetřeným“ bolestem může připadat v úvahu pouze tehdy, pokud při hodnocení výhod a nevýhod ve formě bolestivých stavů lze vyjít ze dvou srovnatelných tělesných stavů (např́klad: s chybným ošetřením a bez něj ztuhlý palec nebo palec s omezenou hybnostî). Pouze v tomto př́padě by mohlo být zjišt'ováno, zda při , ,výsledném stavu“ (jako prri majetkové újmě), který vznikl v důsledku škodní události, vznikly také započitatelné „,výhody“. To zde ale není tento prípad.] 
Odůvodnění tohoto rozhodnutí podléhá doktrinární kritice. ${ }^{55}$ Požadavek na srovnatelné stavy je podle ní nerelevantní. Pokud by jak po skutečném, tak i hypotetickém zákroku zůstal palec nehybný, nebyl opominutý zákrok pro nehybnost palce kauzální. A naopak, pokud by hybnost palce zůstala, nenastala by žádná újma, a tudíž by nebylo co proti čemu zohledňovat.

\subsection{OGH 6 Ob 558/91}

Nejvyšší soud zde posuzoval spor týkající se kosmetické operace. Pacientka požadovala náhradu nemajetkové újmy (bolestné) pro nedostatečné poučení o výsledku kosmetické operace. Oproti očekávání pacientky totiž nedošlo ke kýženému rozšíření dolního rtu, i když část výsledku v podobě zmenšení brady se dostavila. Operace jako taková byla provedena lege artis.

Proti nároku na bolestné soud započetl nemajetkovou výhodu v podobě alespoň částečného zlepšení vzhledu žalobkyně - zmenšení brady. Odůvodnění zápočtu však bylo velmi kusé: stručně řečeno, podle soudu je spravedlivé a v souladu se zásadami teorie vyrovnání újmy prospěchem zohlednit nemajetkovou výhodu snížením nároku na bolestné, což odpovídá zásadě civilního deliktního práva, že poškozený nemá být v lepším postavení než před způsobením újmy. ${ }^{57}$

\subsection{OGH 4 Ob $78 / 08 m^{58}$}

I zde byl předmětem řízení medicínsko-právní spor, tentokrát z oblasti gynekologie a porodnictví. Lékař se dopustil non lege artis postupu, jelikož neprovedl porod císařským řzem. Pacientka požadovala bolestné za bolesti způsobené uskutečněným porodem a za způsobenou psychickou újmu.

55 Viz např. DANZL, K. H., K. GUTIÉRREZ-LOBOS a O. F. MÜLLER. Das Schmeržengeld in mediz̨inischer und juristischer Sicht. 9. vyd. Wien: Manz, 2008, s. 282; shodně PLETZER, R. Vorteilsausgleich beim Schmerzengeld? Juristische Blätter, 2007, roč. 129, č. 7, s. 427.

56 Rozhodnutí OGH ze dne 4.7.1991, 6 Ob 558/91. Dostupné z: https://www.ris.bka.gv.at

57 „Es ist jedoch ein tragender Grundsatz des Schadenersatzrechtes, daß der Geschädigte sich den aus dem schädigenden Ereignis entstandenen Vorteil anrechnen lassen muß. Er soll nicht besser gestellt sein als vor dem Schadenseintritt. Nach den Feststellungen war das Ziel der Klägerin, eine Reduktion der Kinnpartie und damit ein besseres Aussehen zu erreichen. Dies ist zwar nicht in dem in Aussicht genommenen und von ibr erhofften Umfang, aber doch zu einem sebr wesentlichen Teil gelungen. Es erscheint daher billig, nach dem Grundgedanken der Vorteilsausgleichung diesen ihr zugute kommenden Vorteil im Sinne des \ 273 ZPO durch eine Reduktion der Ersatzansprüche auf die Hälfte angemessen zu berücksichtigen. Die Entscheidung des Berufungsgerichtes erweist sich daber im Ergebnis als richtig." [Nosnou zásadou práva na náhradu škody je, že u poškozeného musí být zohledněna výhoda vzniklá ze škodní události. Poškozený nesmí být uveden do lepšího postavení, než byl před vznikem škodní události. Podle provedených zjištění bylo cílem žalobkyně provést zmenšení partií brady, a tím dosáhnout lepšího vzhledu. To ovšem nenastalo v míře a rozsahu žalobkyní předpokládané, ale přesto toho bylo z velké části dosaženo. Proto se jeví jako spravedlivé, v souladu s vưdčí ideou vyrovnání újmy prospěchem, zohlednit jí ku prospěchu vzniklou výhodu ve smyslu \273 ZPO prostřednictvím ponížení nároků na náhradu újmy na polovinu. Rozhodnutí odvolacího soudu se proto ukazuje ve výsledku jako správné.]

58 Rozhodnutí OGH ze dne 10.6.2008, 4 Ob 78/08m. Dostupné z: https://www.ris.bka.gv.at 
Soud se zabýval otázkou, zda je třeba při výpočtu bolestného zohlednit bolesti ušetřené tím, že pacientka reálně nemusela podstoupit porod císařským řezem (při alternativním jednání v souladu s právem by jej musela podstoupit).

Zohlednění nemajetkové výhody v podobě ušetřených bolestí soud nepřipustil, jelikož $\mathrm{v}$ př́padě porodu hypotetického by na straně žalobkyně došlo k týmž tělesným bolestem jako v případě skutečně uskutečněného porodu. $V$ takové situaci žalovaný za újmu neodpovídá (absentuje prř́činná souvislost), a není tedy jakékoliv zohlednění prospěchu na místě..$^{59}$

Srovnáme-li odůvodnění tohoto rozhodnutí s odůvodněním rozhodnutí $5 \mathrm{Ob}$ 242/03d výše, je zřejmé, že navzájem kolidují. V rozhodnutí 5 Ob 242/03d soud jako východisko pro připuštění vyrovnání újmy prospěchem vyžadoval srovnatelný výsledný zdravotní stav poškozeného. Jak již bylo ale uvedeno, doktrína tuto podmínku kritizuje, jelikož $\mathrm{v}$ případě srovnatelných stavů absentuje prríčinná souvislost mezi protiprávním jednáním a újmou. A právě v rozhodnutí $4 \mathrm{Ob} 78 / 08 \mathrm{~m}$ dle soudu srovnatelný výsledný stav nastal a soud (shodně s názorem doktríny a odlišně od rozhodnutí 5 Ob 242/03d) vyrovnání újmy prospěchem odmítnul poukazem na absenci př́činné souvislosti mezi protiprávním jednáním a újmou.

\subsection{BGHZ 86, $240^{60}$}

V posuzovaném případě lékař nerozpoznal, že těhotná pacientka onemocněla spalničkami, přičemž se jí v důsledku této nemoci narodila těžce postižená dcera. Pacientka tvrdila, že pokud by o onemocnění spalničkami věděla, podstoupila by interrupci. Po zdravotnickém zařízení požadovala mj. bolestné za provedený císařský řez.

59 „Die Erwägungen in Literatur und Rechtsprechung zum Ausgleich ,ersparter ${ }^{\prime}$ Schmerzen bei der Zuerkennung von Schmerzengeld bedürfen im vorliegenden Fall keiner Erörterung. Es stebt nämlich fest, dass in jedem Fall eine Entbindung stattfinden musste und die Zweitklägerin zufolge Nichtvornahme des indizierten Kaiserschnitts nicht mehr Schmerzen erdulden musste, als sie im Fall einer von Anfang an geplanten Entbindung mittels Kaiserschnitts hätte erleiden müssen. Die Zweitklägerin hätte demnach bei rechtmäßigem Alternativverbalten des Beklagten die gleichen körperliche Schmerzen wie bei der konkreten Behandlung gelitten. Damit hat der Behandlungsfehler des Beklagten aber nur ein Maß an körperlichen Schmerzen verursacht, das mit dem im Fall sachgerechter Behandlung identisch ist. Bei dieser Sachlage hat der rechtswidrig Handelnde nach herrschender Auffassung für den Schaden nicht einzustehen (Karner in $K B B^{2} \int 1295$ ABGB Rz 14 mwN; Harrer in Schwimann, $A B G B^{3} \int 1301 \mathrm{Rz} 51,54$ mwN). Er baftete nur für ein Mehr an Schmerzen. Reischauer in Rummel, $\left.A B G B^{2} \int 1312 \mathrm{R} z 19 a\right)$. " UÚvahy obsažené v literatuře a judikatuře týkající se vyrovnání „ušetřených“ bolestí při přiznání bolestného nepotřebují v projednávaném př́padě bližší zmínku. Je postaveno najisto, že porod se musel odehrát v každém případě a druhá žalobkyně v důsledku neprovedení indikovaného císařského řezu nemusela snášet větší bolesti, než by musela snášet $\mathrm{v}$ př́padě od počátku plánovaného porodu císařským řezem. Druhá žalobkyně by tedy i v případě alternativního jednání žalovaného v souladu s právem utrpěla shodné tělesné bolesti jako při konkrétním ošetření. Pochybení žalovaného zpo̊sobilo pouze takovou míru tělesné bolesti, která by $\mathrm{v}$ případě správného postupu byla shodná. Za těchto skutkových okolností není podle převládajícího názoru protiprávně jednající škůdce za takovou újmu odpovědný (Karner in KBB² J 1295 ABGB Rz 14 mwN; Harrer in Schwimann, $\mathrm{ABGB}^{3}$ S $\left.1301 \mathrm{Rz} 51,54 \mathrm{mwN}\right)$. Ale odpovídá pouze za bolesti způsobené nad tento rámec. Reischauer in Rummel, $\mathrm{ABGB}^{2}$ \ $\left.1312 \mathrm{Rz} 19 \mathrm{a}\right)$.]

60 Rozhodnutí BGHZ ze dne 18.1.1983, 86, 240 (241). Dostupné z: https://dejure.org 
Soud dospěl k názoru, že při určování výše nároku na bolestné je třeba zohlednit nemajetkovou výhodu v podobě ušetřeného interrupčního zákroku. ${ }^{61}$

\subsection{BGHZ NJW 1995, $2412^{62}$}

Ve zdejším sporu žalobkyně otěhotněla, avšak lékař těhotenství nerozpoznal (přehlédnul) a současně pacientce předepsal léky, které mohly zpơsobit těžké poškození plodu. Pacientka mimo jiné požadovala náhradu za bolesti způsobené psychickou zátěží spočívající v obavě, že se jí narodí postižené dítě.

Nemajetkovou výhodou, kterou soudy posuzovaly, byl ušetřený interrupční zákrok. Nejvyšší soud zohlednění nemajetkové výhody oproti požadovanému bolestnému odmítnul, a to poukazem na skutečnost, že pacientka bolestné požadovala za způsobené psychické bolesti (a nikoliv za bolesti způsobené porodem dítěte). ${ }^{63} \mathrm{Z}$ hlediska doktrinárního zařazení kritérií posuzování prrípadů vyrovnání újmy prospěchem lze odůvodnění tohoto rozhodnutí zařadit pod kategorii „,vnitřního vztahu“ (kongruence) mezi nevýhodou (újmou) a výhodou.

\subsection{OLG Köln 5 U 86/08}

V řízení se jednalo o požadavek pacientky na náhradu nemajetkové újmy - bolestné $z$ důvodu provedení operace $v$ širším rozsahu, než pro jaký pacientka udělila informovaný souhlas. Zákrok měl spočívat toliko v antirefluxní plastice, lékař však pacientce rovněž

61 „Bei der Bemessung dieses Schmerzensgeldes könnte allerdings wiederum in Betracht zu ziehen sein, daß der Mutter so ein - wie jedenfalls behauptet - nicht ganz einfacher Abtreibungseingriff erspart worden ist, dem sie sich bei vertragsmäßigem Verhalten des Beklagten unterzogen hätte. "[Při stanovení bolestného může být opět vzato v úvahu, že matka - jak je v každém případě tvrzeno - byla ušetřena nikoliv zcela jednoduchého potratu, kterému by se při jednání žalovaného v souladu se smlouvou byla nucena podrobit.]

62 Rozhodnutí BGH ze dne 30. 5.1995, NJW 1995, 2412. Dostupné z: https://dejure.org

63 „Im Ergebnis zu Recht wendet sich die Revision dagegen, daß das Berufungsgericht der Klägerin Schmerzensgeld auch deshalb versagt hat, weil ihr ein Abtreibungseingriff erspart geblieben sei... Die Klägerin stützt nämlich den Schmerzensgeldanspruch nicht auf die Unterlassung eines Abbruchs, sondern nur auf die oben zu 1. erörterten besonderen Belastungen durch das späte Erkennen der Schwangerschaft... Der erkennende Senat hat diesen Gesichtspunket in der in BGHZ 86, 240, 248 f. abgedruckten Entscheidung (übrigens auch nur als einen denkbaren Bemessungsfaktor) nämlich lediglich für solche Fälle in Betracht gezogen, in welchen sich bei durch ärz̨tliches Feblverhalten unterbliebenem Schwangerschaftsabbruch ein Schmerzensgeld aus besonderer Schmerzbelastung ergeben kann, die schadensbedingt die mit einer natürlichen, komplikationslosen Geburt verbundenen Beschwerden übersteigt. Eine derartige Schmerzbelastung wird jedoch von der Klägerin nicht geltend gemacht. "[Ve výsledku se dovolání oprávněně obrací proti tomu, že odvolací soud žalobkyni nepřiznal bolestné i z toho důvodu, že byla ušetřena potratu... Žalobkyně totiž neodůvodňuje svůj nárok na bolestné opomenutím provedení potratu, ale pouze na základě shora uvedených zvláštních obtíží vzniklých v důsledku pozdě diagnostikovaného těhotenství... Předmětný senát tento aspekt uvedený ve vydaném rozhodnutí BGHZ 86, 240, 248 f. (ostatně také pouze jako v úvahu prricházející hodnotící faktor) zohledňuje totiž toliko $\mathrm{v}$ takových prrípadech, $\mathrm{v}$ nichž nárok na bolestné plyne ze zvláštních obtíží způsobených opominutím provedením potratu, které v důsledku způsobení škody převyšují prrirozeně se vyskytující obtíže spojené s běžným porodem bez komplikací. Takové bolesti (obtíže) žalobkyně ale neuplatnila.]

64 Rozhodnutí OLG Köln ze dne 1.12.2008, 5 U 86/08. Dostupné z: https://dejure.org 
odstranil část ledvin, která vykazovala onemocnění. Operace proběhla zdárně (lege artis), nicméně důsledkem jejího rozšíření byl vznik rizika dalších onemocnění (infekce, vysoký krevní tlak, ledvinové kameny atp.).

Výhodou, která měla být zohledněna proti újmě spočívající v prodloužení doby operace, bylo odstranění nebezpečí plynoucí z onemocnění ledvin. Soud dospěl k závěru, že uvedená výhoda plně převáží způsobenou újmu, pročež nárok žalobkyně na bolestné nepřiznal. ${ }^{65}$ Soud prri porovnávání odkázal na nutnost hodnotového úsudku (wertende Betrachtung). ${ }^{66}$

\subsection{Shrnutí}

Z uvedené judikatury lze vysledovat následující kritéria, podle nichž soudy posuzovaly př́pustnost zohlednění nemajetkové výhody oproti nároku na bolestné:

- prŕíčinná souvislost (škodní událost jako příčina nevýhody i výhody);

- určitý vnitřní vztah mezi výhodou a nevýhodou (kongruence);

- funkce, smysl a účel civilního deliktního práva (kompenzace, prevence);

- „obecný“ hodnotový úsudek (spravedlnost, přiměřenost atp.).

\section{Doktrína a jednotlivá kritéria vyrovnání nemajetkové újmy při ublížení na zdraví ideálními výhodami}

Více než sto let se nejen doktrína snažila hledat univerzální pravidlo pro posuzování př́padů vyrovnání újmy prospěchem. Snažení to bylo marné. Jakékoliv komplexní pravidlo bylo bud' vystavěno na řadě výjimek, nebo naopak tak neurčitě formulováno, že v důsledku trpělo absencí nutné vypovídací hodnoty. ${ }^{67}$ Jednoznačná a dogmaticky odolná kritéria se najít nepodařilo, shoda nicméně panuje na tom, že mezi výhodou a nevýhodou musí existovat jistá spojitost, vnitřní vztah. ${ }^{68}$

65 „Eine Ersatzpflicht der Beklagten besteht jedenfalls deshalb nicht, weil die Beseitigung der doppelten Nierenanlage links nicht zu einem Schaden der Klägerin geführt hat. Die Erweiterung der Antirefluxplastik um die Entfernung des oberen Anteils der linken Niere war medizinisch indiziert und ist erfolgreich verlaufen. Die Verlängerung der Operationsdauer, auf die die Klägerin allein zu verweisen vermag, begründet aus den im Senatsbeschluss vom 3.11.2008 bereits dargelegten Gründen keinen Schaden. Ein hierin liegenden Nachteil wird dadurch kompensiert, dass die Klägerin nicht mehr mit den aus dem Fortbestehen einer doppelten Nierenanlage resultierenden Gefabren belastet war und ist." [Povinnost žalovaného k náhradě nevzniká, protože odstranění zdvojené ledviny vlevo nevedlo k újmě žalobkyně. Rozšíření antirefluxní plastiky o odstranění vrchní části levé ledviny bylo medicínsky indikované a proběhlo úspěšně. Prodloužení doby operace, na které je žalobkyně schopna odkázat, nepředstavuje újmu, a to z důvodů již uvedených v rozhodnutí senátu ze dne 3.11.2008. V důsledku toho je vzniklá nevýhoda kompenzována tím, že žalobkyně není nadále zatěžována nebezpečími spojenými s další existencí zdvojené ledviny.]

66 „Schon die Befreiung von den gesundheitlichen Risiken ist bei wertender Betrachtung als ein die verlängerte Operationsdauer aufwiegender Vorteil anzusehen. " Již pouhou eliminaci zdravotních rizik je z hodnotícího pohledu nutno posuzovat jako výhodu vyrovnávající prodlouženou dobu trvání operace.]

67 KUHN, R. Die Anrechnung von Vorteilen im Haftpflichtrecht. Bern; Stuttgart: Paul Haupt Bern und Stuttgart, 1987, s. 2 a násl.

68 PLETZER, R. Vorteilsausgleich beim Schmerzengeld? Juristische Blätter, 2007, roč. 129, č. 7, s. 417. 
Přesto, jak bylo uvedeno v předchozím oddílu, určitá kritéria vytvořena byla, i když ne vždy obecně použitelná a kýženě odolná. Právě na rozbor těchto kritérií samostatně a ve vzájemném vztahu se zaměřuje následující text.

\subsection{Ekvivalence př́ičinné souvislosti}

Prvotním determinantem přípustnosti zohlednění nemajetkové výhody oproti nemajetkové újmě na zdraví je teorie ekvivalence v rámci posuzování př́čcinné souvislosti. ${ }^{69}$ Nejde zde o nic jiného než o aplikaci conditio sine qua non testu ${ }^{70}$, viz např. čl. 3:101 PETL ${ }^{71}$, jenž zní: „Jednáni nebo opomenutí (dále jen jednání) je príčinou škody poškozeného, jestliže by pri neexistenci takového jednání škoda nevznikela. "72 Test je vystavěn na metodě tzv. fiktivní eliminace jevů, přičemž fiktivně eliminujeme výhody, a nikoliv nevýhody (újmy).

Uved’me jednoduchý př́klad inspirovaný judikaturou. Chirurg provádí operační zákrok pacientovi v břišní dutině, spočívající v odstranění slepého střeva, chirurgický zákrok jako takový je proveden lege artis, nicméně po jeho skončení operatér v břriše zapomene tampon, což vedle zánětu vede $\mathrm{k}$ dalším komplikacím a nutnosti reoperace. Pacient po lékaři nárokuje bolestné. Lékař požaduje oproti nemajetkové újmě zohlednit nemajetkovou výhodu v podobě řádně resekovaného slepého střeva.

Námitku lékaře je třeba odmítnout. Příčinou vzniku nemajetkové výhody není chyba lékaře spočívající v zanechání tamponu v operační ráně, nýbrž samotná resekce slepého střeva. Jinak řečeno, odmyslíme-li chybu lékaře, nemajetková výhoda stejně nastane. Metodou faktické eliminace jsme tudíž zjistili, že nemajetková výhoda nevznikla v důsledku chyby lékaře, a proto ji není možné zohlednit při zjišt'ování výše bolestného za komplikace způsobené zanecháním tamponu v operační ráně.

\subsection{Adekvátnost příčinné souvislosti}

Teorie adekvátnosti kauzálního nexu slouží v deliktním právu k redukci jinak relativně bezbřehé kauzality zjišt'ované na základě teorie ekvivalence. Omezení prričitatelnosti se děje za pomoci objektivních determinantů, škůdce neodpovídá za atypické újmy

69 SCHIEMANN, G. In: HUBER, Ch., D. JAEGER a J. LUCKEY. Festschrift für Lothar Jaeger zum 75. Geburtstag. Luchterhand Verlag, 2014, s. 413.

70 ZIMMERMANN, R. In: WINIGER, B., H. KOZIOL, B. KOCH a R. ZIMMERMANN (eds.). Digest of European Tort Law. Essential Cases on Natural Causation. New York: Springer Wien New York, 2007, s. 99.

71 Principy evropského deliktního práva. Dostupné z: http://www.egtl.org/PETLCzech.html

72 Obdobně nález Ústavního soudu sp. zn. I. ÚS 312/05: „Východiskem z jištěni právně relevantní príčinné souvislosti je tedy zásadně prokázání prícinné souvislosti v prísněprírodovédném smyslu. Abychom mobli hovorìt o takovém kausálnim vžtahu mezi dvèma skutečnostmi, je nutné, aby skutečnost, keterá má být prǐčinou, byla nutnou podminkou (,condicio sine qua non') toho, že se následek uskutečnil právè tak, jak, se uskutečnil, tj. daným zpoisobem, v daném čase a v daném mistě. Pro výsledek. je príčinnou taková událost, kterou si nelž odmyslet, aniž by nutně odpadl i sám výsledek. (škoda)." 
nastalé za výjimečného (neobvyklého) spojení jevư. ${ }^{73}$ Základním kritériem, ze kterého vychází teorie adekvátnosti, je předvídatelnost škodního následku. ${ }^{74}$ To vše za účelem garance objektivní možnosti pro škůdce zabránit škodnímu následku. ${ }^{75}$

Tuto teorii však nelze převzít bez dalšího na prípady vyrovnání újmy prospěchem. Ten nezákladnější princip deliktního práva zní: casum sentit dominus, přičemž přesun břemene nést újmu na někoho jiného než poškozeného vyžaduje v soukromém právu bilaterální justifikaci. ${ }^{76}$ Jednotlivé skutkové podstaty civilního deliktního práva pak tuto kautelu naplňují, včetně požadavku na adekvátnost kauzálního nexu. To platí právě pro přesun újem, ale zřejmě nikoliv pro přesun výhod. Vznikne-li totiž výhoda, jedná se o štěstí, které se prripisuje osobě, v jejíž sféře vznikla ${ }^{77}$, což pravidelně nebývá škůdce, nýbrž poškozený. Stejně tak při zohledňování výhod nedochází k prrímé regulaci chování škůdce, není tedy třeba garantovat škůdci objektivní možnost vyhnout se způsobení škodnímu následku prostř̌ednictvím předvídatelnosti.

U prrípadů vyrovnání újmy prospěchem tedy nelze princip adekvátní příčinné souvislosti užít jako pozitivní kritérium pro určení přípustnosti zohlednění výhody oproti újmě, jinak řečeno, adekvátnost zpơsobení výhody neznačí automatickou př́ipustnost jejího zohlednění oproti nevýhodě. Německá i rakouská judikatura a doktrína jej ale připouští jako negativní determinant, tedy že neadekvátní výhody se nezohledňují, a pokud je výhoda adekvátní, neznamená to obecně její zohlednění, nýbrž toliko „postup do dalšího kola“, tedy nutnost aplikace dalších kritérií. Jinak řečeno, teorie adekvátnosti je dalším, ale nikoliv posledním filtrem prrípustnosti zohlednění určité výhody proti újmě. ${ }^{78}$

73 HARRER, F. In: SCHWIMANN, M. ABGB Praxiskommentar. Band 6. $\iint$ 1293-1502 ABGB. 3., přepracované vyd. Wien: LexisNexis ARD Orac, 2006, s. 59.

74 Viz např̀. nález Ústavního soudu ze dne 1.11.2007, sp. zn. I. ÚS 312/05.

75 LANGE, H. a G. SCHIEMANN. Schadensersatæ. 3., přepracované vyd. Tübingen: Mohr Siebeck, 2003 , s. 493.

76 BYDLINSKI, F. In: TICHÝ, L. (ed.). Causation in Law. Praha 2007. Beroun: IFEC, 2007, s. 24-25.

77 SCHIEMANN, G. In: HUBER, Ch., D. JAEGER a J. LUCKEY. Festschrift für Lothar Jaeger zum 75. Geburtstag. Luchterhand Verlag, 2014, s. 413 a násl.

78 Viz např. PLETZER, R. Vorteilsausgleich beim Schmerzengeld? Juristische Blätter, 2007, roč. 129, č. 7, s. 414; Rozhodnutí BGH ze dne 17.5.1984, VII ZR 169/82. Dostupné z: https://dejure.org

„Die im Bereich des Schadensersatzrechts entwickelten Grundsätz̧e der Vorteilsausgleichung beruben auf dem Gedanken, daß dem Geschädigten - jedenfalls in gewissem Umfang - diejenigen Vorteile zuzurechnen sind, die ihm in adäquatem Zusammenhang mit dem Schadensereignis zufließen. Es soll ein gerechter Ausgleich zwischen den bei einem Schadensfall widerstreitenden Interessen herbeigefübrt werden. Der Geschädigte darf nicht besser gestellt werden, als er ohne das schädigende Ereignis stünde; das wäre ein unbilliges Ergebnis. Andererseits sind nicht alle durch das Schadensereignis bedingten Vorteile auf den Schadensersatzanspruch anzurechnen, sondern nur solche, deren Anrechnung mit dem jeweiligen Zweck des Ersatzanspruchs übereinstimmt, d.h. dem Geschädigten zumutbar ist und den Schädiger nicht unangemessen entlastet. "[Základní zásady vyrovnání nevýhod prospěchem vytvořené v oblasti práva na náhradu škody spočivají v myšlence, že poškozenému jsou - vždy v určitém rozsahu - přičitatelné takové výhody, které mu vznikají v adekvátní prríčinné souvislosti se škodní událostí. Mělo by být dosaženo spravedlivé rovnováhy mezi protikladnými zájmy vznikajícími způsobením škody. Poškozený nesmí být uveden do lepší pozice, než ve které by se nacházel bez škodní události; jednalo by se o nespravedlivý výsledek. Naproti tomu ne všechny výhody způsobené škodní událostí mají být započteny proti nároku na náhradu újmy, ale pouze takové, jejichž započtení se shoduje s př́slušným účelem nároku na náhradu újmy; tzn. pro poškozeného je přijatelné a současně škůdce nepřiměřeně nezprošt’uje povinnosti k náhradě.] 


\subsection{Specifický vnitřní vztah mezi výhodou a nevýhodou (kongruence)}

Dalším z doktrinárních i judikatorních kritérií, které lze užít pro posuzování případů zohlednění výhod oproti nemajetkové újmě při ublížení na zdraví, je kategorie určitého specifického vztahu mezi výhodou a nevýhodou. ${ }^{79}$ Právě tento determinant umožňuje vytvořit skupiny obdobných př́padů (Fallgruppen), podle kterých se v současnosti dominantě př́ipady vyrovnání újmy prospěchem posuzují.

Podle Cantzlera ${ }^{80}$ tento vztah existuje, pokud výhoda současně podporuje zasažený právní statek, v tomto př́padě zdraví. A to proto, že zákonodárce spojuje odpovědnost (povinnost $\mathrm{k}$ náhradě újmy) s porušením právem chráněných statků. Logicky se pak výhoda, která zasažený právní statek podporuje, musí ve prospěch škůdce zohlednit.

Thiele $^{81} \mathrm{v}$ této souvislosti vychází z myšlenky nerozlučného vztahu, at' už v podobě organické nebo hospodářské. Rakouská judikatura ${ }^{82}$ požaduje věcnou a časovou kongruenci, ta existuje např́klad mezi ušetřenými náklady na domácnost (výhoda) a náhradou za náklady spojené s pobytem $\mathrm{v}$ nemocnici (léčením).

Požadavek na shodný druh výhody a nevýhody je v německém právu zakotven i v zákoně, konkrétně např́iklad v první větě ustanovení \116 I SGB ${ }^{83}$, která upravuje zákonnou cesi práva na náhradu újmy $\mathrm{v}$ prípadě poskytovatelů sociální pomoci.

Problematická je určitost tohoto kritéria při posuzování jednotlivých př́ípadů, jelikož značně odvisí od hodnotového úsudku osoby posuzující předmětné výhody a nevýhody. Dalo by se říci, že toto kritérium určuje kýžený stav, ale už nepopisuje, jak k němu dospět. Inherentní je mu interpretační rozkolísanost. ${ }^{84}$

79 HARRER, F. In SCHWIMANN, M. ABGB Praxiskommentar. Band 6. $\iint 1293-1502$ ABGB. 3., přepracované vyd. Wien: LexisNexis ARD Orac, 2006, s. 403; GRÜNEBERG, Ch. In: PALANDT, O. (Hrsg.). Bürgerliches Gesetz̧buch. 78., přepracované vyd. München: C. H. Beck, 2019, s. 298.

80 CANTZLER, K. Die Vorteilsausgleichung beim Schadensersatzanspruch. Archiv für die civilistische Praxis, 1957 , roč. 156 , č. 1 .

81 THIELE, W. Gedanken zur Vorteilsausgleichung. Archiv für die civilistische Praxis, 1967, roč. 167, č. 3.

82 Rozhodnutí OGH ze dne 23.11.1971, 8 Ob 298/71. Dostupné z: https://www.ris.bka.gv.at: „Die Berücksichtigung der Haushaltsersparnis unter dem Gesichtspunkt der Vorteilsausgleichung kommt nur gegenüber sachlich und zeitlich kongruenten Schadenersatzansprüchen des Geschädigten, worunter die von ihm zu zablenden Spitalskosten fallen, in Betracht." [Zohlednění ušetřených výdajů na domácnost z pohledu vyrovnání nevýhod prospěchem přichází v úvahu pouze oproti věcně a časově kongruentním nárokủm na náhradu škody poškozeného, mezi něž patři i náklady hrazené poškozeným na pobyt v nemocnici.]

83 Dostupné z: https://www.gesetze-im-internet.de/sgb_10/_116.html: „Ein auf anderen gesetzlichen Vorschriften berubender Anspruch auf Ersatz eines Schadens gebt auf den Versicherungsträger oder Träger der Eingliederungshilfe oder der Sozialbilfe über, soweit dieser auf Grund des Schadensereignisses Sozialleistungen zu erbringen hat, die der Bebebung eines Schadens der gleichen Art dienen und sich auf denselben Zeitraum wie der vom Schädiger zu leistende Schadenersatz beziehen. " [Nárok na náhradu škody zakládající se na jiném právním předpisu přechází na pojistitele nebo poskytovatele dávky na začlenění nebo sociální pomoci, pokud tento je povinen $\mathrm{v}$ důsledku škodní události poskytnout sociální dávky (plněnî), které slouží k napravení škody shodné povahy a které se vztahují ke stejnému časovému období jako škůdcem poskytnutá náhrada škody.]

84 PLETZER, R. Vorteilsausgleich beim Schmerzengeld? Juristische Blätter, 2007, roč. 129, č. 7, s. 415. 
Příkladmo lze uvést, že kongruence bude existovat mezi bolestným za újmu na zdraví a výhodou $v$ podobě zlepšení zdraví, což jsou již výše zmíněné judikatorní příklady. Jak u výhody, tak nevýhody, jde o zasažení a podporu shodného právního statku. Naopak kongruence jistě nebude existovat mezi újmou na zdraví a náhradou za ztrátu na výdělku, zde jsou oba právní statky zcela jiného charakteru, navíc imateriálního a materiálního.

Úzce související kategorií s požadavkem na kongruenci výhod a nevýhod je účel normy, resp. smlouvy ${ }^{85}$, na základě které partikulární výhoda vzniká, typicky jde o různé dávky sociálního zabezpečení či pojistná plnění. Inspirací pro tuto kategorii je pro deliktní právo inherentní ochranný účel normy. ${ }^{86}$

V případě účelu normy, na základě které výhoda vznikla, zkoumáme jeho vztah k nevýhodě (újmě). Př́kladmo lze poukázat na české rozhodnutí Ústavního soudu ${ }^{87}$, resp. soudu Nejvyššího ${ }^{88}$. Skutkově se jednalo o případ, v němž poškozená požadovala náhradu újmy v podobě účelně vynaložených nákladů na léčení podle ustanovení \ 449 odst. 1 občanského zákoníku z roku $1964^{89}$, konkrétně náhradu nákladů vynaložených na zajištění pomoci při základních životních úkonech a na zajištění chodu domácnosti. Soudy se musely vypořádat s otázkou, zda je třeba od této náhrady odečíst příspěvek na péči poskytovaný podle ustanovení $\int 7$ zákona o sociálních službách ${ }^{90}$. V odůvodnění zvažovaly ve vztahu k této kategorii dvě skutečnosti, proč příspěvek na péči při stanovení výše náhrady zohlednit. Za prvé, smysl a účel výhody podle normy ji upravující („,...jejím účlem, jak vyplývá z textu zákona i z dìvodové zprávy, je umožnit osobè, jejiž dloubodobè nepríznivý zdravotni stav vyžaduje péci jiných osob, zajištèni potrebné pomoci prí péči o vlastni osobu a pri zajištèni sobèstačnosti..."), a za druhé, smysl a účel výhody ve vztahu k normě regulující povinnost k náhradě újmy („... Poškozenému tedy př̌spěvek na péči náleži zue stejného di̛vodu, jako je ten, na némžje založena prípadná povinnost škùdce nabradit škodu...").

Od účelu normy, na základě které došlo ke vzniku výhody, je třeba odlišovat účel (funkce) civilního deliktního práva, tedy včetně té které skutkové podstaty civilního deliktního práva upravující povinnost škůdce k náhradě újmy, viz následující pododdíl.

85 PLETZER, R. Vorteilsausgleich beim Schmerzengeld? Juristische Blätter, 2007, roč. 129, č. 7, s. 415.

86 Viz např. DOLEŽZAL, A. a T. DOLEŽZLL. Kauzalita v civilním právu se zaméreném na medicinskoprávni spory. Praha: Ústav státu a práva AV ČR, 2016, s. 100: „Zjednodušeně ré̌éno, vycház̨i teorie o ochranném účelu normy z toho, že jak smluvni povinnosti, tak zákonné normy upravujici odpovédnost za üjmu a s nimi souvisejici konkrétní povinnosti opatrnosti (Verkehrspflichten) slouži ochranè pouze určitých zájmů. Ochrana téchto zájmů je v normách bud" prímo vyjádrena, nebo ji lze teleologickým výkladem dovodit."

87 Usnesení Ústavního soudu ze dne 28. 1. 2020, sp. zn. III. ÚS 4194/18.

88 Rozsudek Nejvyššího soudu ze dne 26. 9.2018, sp. zn. 25 Cdo 3157/2018.

89 Zákon č. 40/1964 Sb., občanský zákoník, ve znění pozdějších předpisů.

90 Zákon č. 108/2006 Sb., o sociálních službách, ve znění pozdějších předpisů. 


\subsection{Funkce, smysl a účel civilního deliktního práva}

Při posuzování př́padů vyrovnání nemajetkové újmy prospěchem je dále zapotřebí zohlednit funkce, smysl a účel civilního deliktního práva, resp. náhrady za způsobenou nemajetkovou újmu na zdraví. Výhodu je možné oproti nevýhodě zohlednit jen v případě, že je takový postup v souladu s těmito kritérii. ${ }^{11}$

\subsubsection{Kompenzačni funkece}

Primární funkcí civilního deliktního práva je kompenzace, resp. vyrovnání újmy. ${ }^{92}$ To lze v českém právu vysledovat ihned z názvu interlineární rubriky, která tuto oblast práva uvozuje: „Náhrada majetkové a nemajetkové uijmy. "Shodné platí např́klad i pro rakouské a německé právo. ${ }^{93}$ Cílem kompenzace je vyrovnat veškerou zpơsobenou újmu a nikoliv více, tedy současně zabránit obohacení poškozeného poskytnutou náhradou (Bereicherungsverbot). ${ }^{94}$

$\mathrm{V}$ případě nemajetkové újmy se ale nehovoří ryze o kompenzační funkci náhrady. Podle ustanovení \2951 odst. 2 OZ se nemajetková újma odčiní přiměřeným zadostiučiněním, a to i ve formě peněžitého plnění. V německém právu jde o tzv. spravedlivé odškodnění v penězích (billige Entschädigung in Geld). ${ }^{95}$ Je tomu tak z důvodu zásadní nevyčíslitelnosti nemajetkových statků v penězích. I když je zřejmé, že peněžitá náhrada stricto sensu utrpěnou nemajetkovou újmu nevyrovná, užívá se jí v těchto prrípadech z důvodu, že společnost, resp. právo nezná jiný vhodnější způsob odčinění tohoto druhu újmy. Vyrovnání nemajetkové újmy je pouhým normativním konstruktem, ${ }^{96}$ cílem zadostiučinění je opatření si náhradních hodnot, které pomohou poškozenému překonat př́íkoří spojené se zásahem do nemateriálních statků. $V$ př́padě újmy na zdraví jde primárně o znovunastolení rovnováhy osobnosti poškozeného. ${ }^{97}$

\subsubsection{Prevenćni funkece}

Prevenční, resp. odrazující funkci lze vymezit jako nástroj pro předcházení vzniku újem odrazující škůdce $\mathrm{v}$ negativním působení na právem chráněné statky. ${ }^{98} \mathrm{~V}$ současnosti je tato funkce relativizována nejen zákonným, ale i smluvním pojištěním.

91 GRÜNEBERG, Ch. In: PALANDT, O. (Hrsg.). Bürgerliches Geseţ̧buch. 78., přepracované vyd. München: C. H. Beck, 2019, s. 297 a násl.

92 KOZIOL, H. Basic questions of tort law from a Germanic perspective. Wien: Jan Sramek Verlag, 2012, s. 75 a násl.

93 Viz ustanovení \ 1295 ABGB a 823 BGB.

94 KOZIOL, H. Österreichisches Haftpflichtrecht. Allgemeiner Teil. 3., přepracované vyd. Wien: Manz, 1997, s. 326 a násl.

95 Viz ustanovení \253 BGB.

96 KARNER, E. Der Ersatz ideeller Schäden bei Körperverletzung. Springer Verlag: Wien, 1999, s. 133.

97 HARRER, F. In: SCHWIMANN, M. ABGB Praxiskommentar. Band 6. IJ 1293-1502 ABGB. 3., přepracované vyd. Wien: LexisNexis ARD Orac, 2006, s. 437.

98 KOZIOL, H. Basic questions of tort law from a Germanic perspective. Wien: Jan Sramek Verlag, 2012, s. 75 a násl. 
V rámci teorie vyrovnání újmy prospěchem to znamená, že nesmí docházet k nespravedlivému zvýhodnění škůdce zohledněním výhody, čímž by docházelo k oslabení prevenčního působení na škůdce. ${ }^{99}$

S prevenční funkcí úzce souvisí i problematika sankční funkce civilního deliktního práva. V českém, a ostatně i německém a rakouském právním řádu, se ale vždy sankční momenty projevují v mezích funkce kompenzační, což znamená, že na náhradě újmy poškozený nesmí obdržet více, než činí jeho skutečná újma. ${ }^{100}$ Angloamerická doktrína punitive damages je v kontinentálním právu odmítána.

\subsubsection{Shrnutí}

Působení kompenzační a prevenční funkce civilního deliktního práva v oblasti vyrovnání újmy prospěchem lze shrnout tak, že výhodu je možné zohlednit oproti nevýhodě jen $\mathrm{v}$ případě, že poškozený na náhradě újmy neobdrží více, než jaká mu byla skutečně způsobena újma, avšak současně ani méně. Jinak řečeno, poškozený ani škůdce nesmí být prostřednictvím náhrady újmy ani bezdůvodně obohacen, ani znevýhodněn.

\subsection{Spravedlnost, přiměřenost}

Posledními kritérii, která na tomto místě budou představena, jsou kautely spravedlnosti, přměřenosti a další podobné. Požadavek, aby zohlednění výhody bylo spravedlivé a přiměřené, plyne nejen z judikatury, ${ }^{101}$ ale i doktríny. Při posuzování jednotlivých př́padů to znamená, že na straně poškozeného musí být zohlednění výhody přiměřené a na straně škůdce zase nesmí dojít k jeho nespravedlivému zvýhodnění.

$\mathrm{V}$ rámci jednotlivých kritérií posuzování případů vyrovnání újmy prospěchem se jedná pravděpodobně o nejvíce abstraktní kritéria, jinak řečeno jde o tzv. neurčité právní pojmy. Jejich obsah je vymezován až konkrétními okolnostmi jednotlivého př́padu, přičemž do popředí vstupuje hodnotový úsudek osoby, jež jejich obsah vykládá. ${ }^{102} \mathrm{~A}$ v rámci teorie vyrovnání újmy prospěchem se jedná o zcela typická kritéria, která celou tuto oblast formují, ${ }^{103}$ problematika vyrovnání újmy prospěchem je branou pro užití hodnot v jinak čistě početním a technicky chápaném právu náhrady újmy. ${ }^{104}$

\footnotetext{
99 Viz výše rozhodnutí OGH 10 Ob 209/02m.

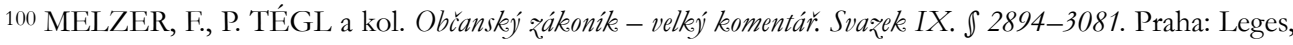
2018, s. 7.

101 Viz např. výše rozhodnutí OGH 10 Ob 209/02m.

102 Např. VELTEN, W. Der medizinische Standard im Arz̧thaftungsprozeß: ein Beitrag zu Umfang und Grenzen der Darlegungslast von Arzthaftungsklägern bezüglich der Standards medizinischer Heilbehandlung. Baden-Baden: Nomos, 2001, s. 38-39.

103 PLETZER, R. Vorteilsausgleich beim Schmerzengeld? Juristische Blätter, 2007, roč. 129, č. 7, s. 417.

104 SCHIEMANN, G. Argumente und Prinzipien bei der Fortbildung des Schadensrechts, München: C. H. Beck, 1981, s. 122.
} 
Ve vztahu k posuzování konkrétních př́ipadů je jejich zřejmým úskalím právě jejich neurčitost. Výstižně uvádí Thüssing ${ }^{105}$, že tato a obdobná kritéria jsou pouhými šiframi aplikace hodnotového úsudku, které toliko proklamují, že se hodnotový soud má učinit, nicméně již neř́ikají, jakým zpơsobem a s jakými závěry. „Jak“ závisí na další precizaci, jinak řečeno, na konkrétních okolnostech jednotlivých př́ípadů, jejichž odůvodnění bude více či méně přesvědčivé a racionálně pochopitelné.

\subsection{Shrnutí}

Kritéria pro posuzování případů vyrovnání újmy prospěchem se historicky vyvíjela a formovala, a to ve světle snahy naleznout univerzální a dostatečně odolné pravidlo. To se v průběhu času ukázalo jako nemožné. ${ }^{106}$ Postupně tak přibývala další kritéria, která určitým způsobem navazovala na kritéria předešlá, nebo je modifikovala (viz např. nejprve kritérium v podobě př́činné souvislosti a následně kritéria specifického vnitřního vztahu mezi újmou a výhodou). Současné snahy vycházejí z tvorby skupin př́padů (Fallgruppen), které se vyznačují obdobnými markanty, přičemž se ukazuje, že robustním a odolným zpo̊sobem jejich posuzování je aplikace nikoliv jednoho vybraného kritéria na konkrétní případ, nýbrž jejich komplexu, což rovněž ilustruje následující oddíl.

\section{Typické skupiny př́ípadů}

V návaznosti na výše zjištěné skutečnosti bude následující pododdíl zaměřen na typické skupiny prípadů zahrnující problematiku vyrovnání nemajetkové újmy při ublížení na zdraví nemateriální výhodou, a to v souvislosti s jednotlivými kritérii uvedenými v předchozím oddílu. Cílem je rozhodnout, zda danou výhodu oproti nevýhodě zohlednit, či nikoliv.

Skupiny př́padů jsou vystavěny na základě typu nemajetkových výhod. ${ }^{107}$ První z nich se týká nemajetkové výhody v podobě zlepšení zdravotního stavu, druhá ušetřených bolestí.

\subsection{Zlepšení zdravotního stavu}

Nemajetková výhoda v této konstelaci spočívá, jak název napovídá, ve zlepšení zdravotního stavu, nejčastěji pacienta. Př́činou zlepšení zdravotního stavu je škodní událost, která dala současně vzniknout nemajetkové nevýhodě - újmě na zdraví. Primárně půjde o non lege artis postup lékaře.

105 THÜSING, G. Wertende Schadensberechnung. München: C. H. Beck, 2001, s. 45.

106 KUHN, R. Die Anrechnung von Vorteilen im Haftpflichtrecht. Bern; Stuttgart: Paul Haupt Bern und Stuttgart, 1987, s. 2 a násl.

107 Tedy návazně na skupiny vytvořené např. v PLETZER, R. Vorteilsausgleich beim Schmerzengeld? Juristische Blätter, 2007, roč. 129, č. 7; V doktríně se objevuje i odlišné třídění typických případů, viz ERM, D. Vorteilsanrechnung beim Schmerzensgeld - ein Beitrag zur Fortentwicklung des Schadens(ersatz)rechts. Karlsruhe: Verlag Versicherungswirtschaft GmbH, 2013, s. 395 a násl. a s. 401, jenž vytvořil celkem čtyři skupiny, nicméně stejně zdůrazňuje, že těžiště případů tkví ve skupinách uváděných Pletzer. 
Pro další výklad je důležité, že porušení právní povinnosti lékaře může tkvět i v nedostatečném poučení pacienta s důsledkem absence informovaného souhlasu jako okolnosti vylučující protiprávnost zásahu do pacientovy integrity.

Jako prríklad reálných skutkových okolností může sloužit již zmíněný případ OGH 6 Ob 558/91 ${ }^{108}$, v němž rakouský Nejvyšší soud posuzoval spor plynoucí z kosmetické operace. Pacientka požadovala náhradu nemajetkové újmy (bolestné) pro nedostatečné poučení o výsledku kosmetické operace. Oproti očekávání pacientky totiž nedošlo ke kýženému rozšíření dolního rtu, i když část výsledku v podobě zmenšení brady se dostavila. Vưči nároku na bolestné požadoval žalovaný zohlednit nemajetkovou výhodu v podobě alespoň částečného zlepšení zdravotního stavu žalobkyně - zmenšení brady.

Aby bylo možné výhodu zohlednit, musí být primárně splněno první kritérium v podobě ekvivalence prríčinné souvislosti, tzn. že protiprávní jednání musí být současně př́ičinnou vzniku nemajetkové výhody. Jinak řečeno, nebýt porušení povinnosti, výhoda by nevznikla. ${ }^{109}$

Důsledně je třeba dbát na splnění tohoto kritéria $\mathrm{v}$ případech, v nichž protiprávní jednání lékaře spočívá v zásahu do pacientovy integrity bez udělení náležitého informovaného souhlasu. ${ }^{110}$ Aby bylo vůbec možné takovým protiprávním jednáním vzniklou výhodu oproti nevýhodě zohlednit, musí být zřejmé, že by pacient př̀ řádném poučení ze strany lékaře informovaný souhlas neudělil (a zákrok nepodstoupil). Pokud by ho totiž pacient udělil i tak, příčinná souvislost mezi protiprávním jednáním a výhodou absentuje, jelikož by výhoda vznikla i prri řádném postupu lékaře.

Dále musí být příčinná souvislost adekvátní. To by však nemělo činit větší problémy. Pro lékaře je i z objektivního hlediska předvídatelné, že jeho zákrokem může dojít ke vzniku předmětné výhody, ostatně s tím zákrok lékař také prováděl.

Nejednoznačnost panuje ve vztahu ke kongruenci a funkcím civilního deliktního práva, pokud se jedná o př́pady zahrnující nedostatečné poučení ze strany lékaře, a to kvưli současnému zásahu do práva na sebeurčení člověka (Selbstbestimmungrecht). ${ }^{111}$

108 Viz pododdíl 2.3.

109 Pokud výhoda vznikne v důsledku řádného plnění povinnosti, nelze ji oproti újmě zohlednit, jelikož není dána faktická příčinná souvislost mezi protiprávním jednáním a vznikem výhody, viz např. případ operatéra uvedený v pododdílu 3.1, jenž v operační ráně ponechal tampon, přičemž za započitatelnou výhodu (nesprávně) považoval zdárný výsledek operace.

$110 \mathrm{~V}$ souvislosti s těmito př́pady je ale na samotném počátku posuzování zapotřebí určit, zda vůbec pacientovi vznikla odčinitelná újma (na zdravî), podrobněji viz DOLEŽAL, T. Právní povaha informovaného souhlasu a následky neúplného poučení z hlediska civilního práva. Časopis qudravotnického práva a bioetiky, 2019, roč. 9, č. 1, zejména kapitola 5 Náhrada újmy a neúplné poučení.

$111 \mathrm{~V}$ této souvislosti je nutné opět prripomenout specifika německé i rakouské judikatury, a to že nárok na náhradu nemajetkové újmy na zdraví je celistvý (jde o tzv. Schmerzensgeld, bolestné), netvoří jej jednotlivé dílčí nároky jako v právu českém a že jakýkoliv zákrok lékaře bez informovaného souhlasu pacienta naplní př́slušnou skutkovou podstatu povinnosti k náhradě újmy na zdraví, čímž pacientovi vznikne právo na bolestné. 
Nejde-li o ně, kongruenci mezi výhodou a nevýhodou lze spatřovat - oba statky jsou nemajetkového charakteru a oba se týkají zdraví člověka. Totéž platí i pro funkce civilního deliktního práva. Jelikož protiprávním jednáním došlo současně ke kompenzaci shodného statku, není dle našeho názoru preventivní funkce jakkoliv potírána. Nebudou-li přítomny další relevantní okolnosti určitého prrípadu, které by odůvodňovaly opak (aplikace principů spravedlnosti, primérenosti atd.), lze kladně rozhodnout o př́pustnosti zohlednění zlepšení zdravotního stavu oproti újmě na zdraví. ${ }^{112}$

Za další relevantní okolnosti určitého případu, které by odůvodňovaly opak, je možné považovat také absenci informovaného souhlasu ze strany pacienta. Rakouská a německá doktrína je při posuzování těchto př́ípadů poněkud rozkolísaná.

Kupř. Pletzer ${ }^{113}$ a Karner ${ }^{114}$ plédují primárně za zohlednění zlepšení zdravotního stavu oproti způsobené újmě na zdraví i při nedostatku v informovaném souhlasu. Odůvodnění spočívá $\mathrm{v}$ tom, že zásah do práva na sebeurčení je pro pacienta lehčí, pokud si uvědomí, že současně protiprávním zákrokem došlo k objektivnímu zlepšení jeho zdraví, že zákrok byl konec konců v jeho prospěch a že tyto okolnosti směřují alespoň k částečnému zadostiučinění (odškodnění) i za zásah do práva na sebeurčení.

Současně oba uvádějí, že $\mathrm{v}$ prrípadech, $\mathrm{v}$ nichž došlo k výraznému zásahu do práva na sebeurčení pacienta, není možné výhodu oproti újmě zohlednit, typicky v prípadě hysterektomie, amputace údů apod. Zde totiž nemajetková výhoda v podobě zlepšení zdravotního stavu není takové intenzity, aby vyrovnala i tak těžký zásah do práva na sebeurčení a z toho plynoucí duševní strádání.

Naopak Erm ${ }^{115}$ či Kerschner ${ }^{116}$ jsou toho názoru, že v prŕípadě nedostatečného informovaného souhlasu nelze s ohledem na zásah do práva na sebeurčení nemajetkovou výhodu v podobě zlepšení zdravotního stavu proti bolestnému započítat, jelikož výhoda a nevýhoda nejsou navzájem kongruentní, účel normy regulující nezbytnost informovaného souhlasu zakazuje svévolné zásahy do integrity člověka a současně chrání i objektivně nerozumná rozhodnutí pacienta nenechat se léčit jako výraz respektu k autonomii vůle člověka, dále jelikož prevenční funkce civilního deliktního práva odrazující škůdce v zásahu do práva na sebeurčení je relativizována a konečně že při zohlednění výhody dojde na straně pacienta de facto k jejímu vnucení. To vše svědčí pro odmítnutí zohlednění výhody v těchto př́ípadech.

\footnotetext{
112 Shodně např. KARNER, E. Der Ersatz ideeller Schäden bei Körperverletzung. Springer Verlag: Wien, 1999, s. 122; PLETZER, R. Vorteilsausgleich beim Schmerzengeld? Juristische Blätter, 2007, roč. 129, č. 7, s. 423.

113 PLETZER, R. Vorteilsausgleich beim Schmerzengeld? Juristische Blätter, 2007, roč. 129, č. 7, s. 423 a násl. 114 KARNER, E. Der Ersatz ideeller Schäden bei Körperverletzung. Springer Verlag: Wien, 1999, s. 122.

115 ERM, D. Vorteilsanrechnung beim Schmerzensgeld - ein Beitrag zur Fortentwicklung des Schadens(ersatz)rechts. Karlsruhe: Verlag Versicherungswirtschaft GmbH, 2013, s. 401.

116 KERSCHNER, F. Schmerzengeld. Kommentar und Judikatur. Verlag Österreich: Wien, 2013, s. 135.
} 
V prríkladmo uvedené judikatuře OGH 6 Ob 558/91 týkající se případu, v němž absentoval informovaný souhlas pacienta, dospěl soud k závěru, že je spravedlivé a v souladu se zásadami teorie vyrovnání újmy prospěchem zohlednit nemajetkovou výhodu snížením nároku na bolestné.

V českém právu bude na rozdíl od práva německého a rakouského při posuzování obdobných př́padů nadto třeba zohlednit skutečnost, že náhrada při ublížení na zdraví se podle ustanovení \2958 OZ „rozpadá“ do tří samostatných nároků, a to na bolestné (náhrada za vytrpěné bolesti), na náhradu za ztížení společenského uplatnění a náhradu za další nemajetkové újmy. Tato skutečnost ovlivní posouzení kongruence a účelu normy, včetně funkcí práva regulujícího povinnost $\mathrm{k}$ náhradě újmy, a to primárně ve vztahu k náhradě za zásah do práva na sebeurčení. Podle charakteru zlepšení zdravotního stavu v konkrétním prípadě bude moci být (s ohledem na výše uvedené) tato výhoda zohledněna při výpočtu bolestného či náhrady za ztížení společenského uplatnění. Dle našeho názoru ale nebude výhoda $\mathrm{v}$ podobě zlepšení zdravotního stavu kongruentní s nevýhodou v podobě zásahu do práva na sebeurčení. Přijmeme-li výklad ${ }^{117}$, že pod další nemajetkové újmy ve smyslu ustanovení \2958 OZ lze podřadit i zásahy do dalších složek osobnosti člověka mimo zdraví, bude za zásah do práva na sebeurčení (část osobnosti člověka) náležet náhrada za další nemajetkové újmy při ublížení na zdraví dle \2958 OZ, a nikoliv současně ostatní náhrady, tedy za vytrpěné bolesti a za ztížení společenského uplatnění. Z toho plyne, že výhoda $\mathrm{v}$ podobě zlepšení zdravotního stavu nemůže být způsobilá současně „,vyrovnat“ nevýhodu (újmu) způsobenou zásahem do práva na sebeurčení.

\subsection{Ušetřené bolesti}

V případě ušetřených bolestí jde o případy, v nichž se nemajetková výhoda projevuje negativně, v absenci bolestivých stavů, které by, nebýt protiprávního jednání, nastaly. Shodně jako v pododdílu 4.1 se tyto výhody vyskytují primárně v oblasti medicínskoprávních sporů. Jednak může jít o případy, kdy v důsledku chybného postupu lékaře pacient „ušetří، bolesti, které by v př́padě, že by k postupu (i když chybnému) vůbec nedošlo, musel vytrpět. Nemajetkovou výhodu v podobě ušetřených bolestí je zapotřebí posoudit vůči újmě na zdraví plynoucí z non lege artis postupu lékaře.

Pro reálné skutkové okolnosti této konstelace viz např. rozhodnutí OGH 4 Ob 78/08m uvedené v pododdílu 2.4. Lékař se zde dopustil non lege artis postupu, jelikož neprovedl porod císařským řezem. Pacientka požadovala bolestné mj. za bolesti způsobené uskutečněným porodem. Soud se zabýval otázkou, zda je třeba při výpočtu bolestného zohlednit bolesti ušetřené tím, že pacientka reálně nemusela podstoupit porod císařským řezem, který by při alternativním jednání v souladu s právem musela podstoupit.

117 Viz např̀ MELZER, F., P. TÉGL a kol. Občanský zákoník - velký komentár. Svazek IX. 』 2894-3081. Praha: Leges, 2018, s. 1004. 
Na druhé straně se může jednat o prrípady spočívající v neprovedení určitého zákroku, který objektivně měl být proveden. Ušetřené bolesti plynou z neprovedení (jinak indikovaného) zákroku, přičemž posoudit je třeba jejich zohlednění vưči újmě na zdraví vzniklé právě pro neprovedení daného zákroku. Typické skutkové okolnosti lze nalézt například v rozhodnutí OGH $5 \mathrm{Ob} 242 / 03 \mathrm{~d}^{118}$, v němž se jednalo o žalobu pacientky na zdravotnické zařízení kvưli chybnému medicínskému postupu spočívajícím v opožděné diagnóze a na to navázaném opominutí včasného operačního zákroku, v důsledku čehož došlo u pacientky ke ztrátě hybnosti prstů. Proti nároku žalobkyně na bolestné požadovalo zdravotnické zařízení započíst nemajetkovou výhodu - ušetření bolesti z včas neprovedené operace, která by byla provedena, nebýt vadné (opožděné) diagnózy.

Odůvodnění závěru o přípustnosti, resp. nepřípustnosti zohlednění výhody v podobě ušetřených bolestí vưči újmě na zdraví způsobené non lege artis provedeným zákrokem dle skutkových okolností prve uvedené modelové situace je obdobné odůvodnění jako v pododdílu 4.1, a to včetně nezbytnosti rozlišování, zda se jedná o non lege artis postup lékaře v důsledku absence informovaného souhlasu, či nikoliv.

Co se týče druhé modelové kazuistiky, tedy případů vyznačujících se chybou lékaře spočívající v neprovedení určitého zákroku (omise), díky čemuž dojde na straně pacienta k ušetření určitých bolestí, opět v rámci doktríny a judikatury nepanuje jednota.

Podle Pletzer ${ }^{119}$ vylučuje aplikaci pravidel vyrovnání újmy prospěchem samotná skutečnost, že bolesti ušetřené neprovedením zákroku nelze považovat za nemajetkovou výhodu, jelikož bolesti spojené s (hypotetickým) zákrokem vznikají za účelem zlepšení zdravotního stavu, pročež lze říci, že se jedná o „pozitivní“ bolesti. Pokud výskyt takových bolestí nelze považovat za újmu, nelze současně jejich absenci považovat za výhodu, kterou by bylo možno zohledňovat vưči reálně vzniklé újmě na zdraví.

$\mathrm{S}$ takovým odůvodněním nesouhlasí kupř. Erm ${ }^{120}$, podle kterého ušetřené bolesti z neprovedení zákroku představují určitý druh újmy, které bylo zabráněno právě kvůli jeho neprovedení. Bolesti by skutečně vznikly, pokud by nedošlo k porušení povinnosti na straně lékaře. S odmítnutím vyrovnání újmy prospěchem souhlasí, přičemž argumentuje odlišně než Pletzer. Do popředí staví osobnostní právo člověka na sebeurčení a ochranný účel normy jej chránící. V případě, že by za vylíčených skutkových okolností došlo k zohlednění ušetřených bolestí vzniklých kvưli neprovedení určitého zákroku, znamenalo by to $\mathrm{v}$ konečném důsledku vnucení takového zákroku, což odporuje právu pacienta (člověka) na sebeurčení. Erm tedy shodně jako Pletzer zapovídá vyrovnání újmy prospěchem $v$ těchto př́padech, avšak argumentuje nenaplněním kritéria v podobě ochranného účelu normy.

118 Viz pododdíl 2.2.

119 PLETZER, R. Vorteilsausgleich beim Schmerzengeld? Juristische Blätter, 2007, roč. 129, č. 7, s. 427.

120 ERM, D. Vorteilsanrechnung beim Schmerzensgeld - ein Beitrag zur Fortentwicklung des Schadens(ersatz)recbts. Karlsruhe: Verlag Versicherungswirtschaft GmbH, 2013, s. 403. 
Podle našeho názoru nebude v těchto případech relevantní zásah do práva na sebeurčení pacienta kvůli vnucení zdravotnického zákroku. Totiž tím, že pacient požaduje náhradu újmy na zdraví spočívající v nezlepšení zdravotního stavu kvưli opomenutí lékaře, současně projevuje vưli, že by opominutý zákrok podstoupil a vyslovil s ním souhlas. Kdyby tomu bylo naopak a pacient by souhlas nevyslovil, nevznikla by újma na zdraví a nebylo by tedy co výhodou vyrovnávat.

Soud, který tento prrípad ve skutečnosti posuzoval, vyrovnání újmy prospěchem také odmítnul, nicméně pro odlišné důvody než Erm a Pletzer. Dle názoru soudu absentovala prŕíčinná souvislost. ${ }^{121}$

\subsection{Shrnutí}

Nastíněná kazuistika zřetelně demonstruje inherentní rysy problematiky vyrovnání újmy prospěchem, tím spíše, pokud se jedná o oblast ideálních právních statků jako je osobnost člověka. Absence univerzálního pravidla pro řešení těchto př́padů včetně nezbytnosti aplikace hodnotového úsudku zohledňujícího veškeré okolnosti má za důsledek značnou rozkolísanost jejich doktrinárního i judikatorního posuzování.

I když jsou závěry německých i rakouských vysokých soudů a doktríny vzájemně nejednotné, patrně se s problematikou vyrovnání nemajetkové újmy na zdraví nabytým prospěchem setkávají častěji než české soudy i doktrína. Proto lze v obou nám blízkých právních rádech hledat cenné poznatky a inspiraci pro výklad těchto prrípadů podle práva českého, a to při respektování odlišností plynoucích z toho kterého právního řádu.

Vedle názorové nejednotnosti týkající se relevantních kritérií a jejich aplikace na výše uvedené př́pady je důležité si také uvědomit, že klíčové pro posuzování prípustnosti vyrovnání nemajetkové újmy na zdraví nabytým ideálním prospěchem (výhodou) je primárně rozhodnout, zda lze domnělou nemajetkovou výhodu považovat za takovou hodnotu, která je zpơsobilá újmu na zdraví (či jiném osobnostním právu) člověka vůbec vyrovnat. Pro zachování nezbytné objektivity je třeba hledat určitou „spodní hranici“. Paralelu lze dle našeho názoru vést shodně jako při rozlišování, co lze rozumět újmou na zdraví a co nikoliv ${ }^{122}$, proto i v prrípadě nemajetkové výhody, jež má být zohledněna vưči nemajetkové újmě na zdraví, musí jít o výhodu, která bude určitým zpơsobem medicínsky zachytitelná. To bude zpravidla splněno např́klad při existenci hybnosti prstů, ušetření bolestí neprovedením invazivního operačního zákroku či porodu. Naopak u výhod objevujících se v judikatuře i doktríně typu nalezení lásky v nemocnici, radosti z narození dítěte apod. bude rozhodnutí o poznání obtížnější a spíše odmítavé.

\footnotetext{
121 Viz výše pododdíl 2.2.

122 MELZER, F., P. TÉGL a kol. Občanský zákoník - velký komentár. Svaz̨ek IX. \ 2894-3081. Praha: Leges, 2018, s. 992.
} 
Přispívat při tomto rozhodování bude patrně také kritérium kongruence, jelikož v jeho rámci se zohledňuje povaha výhody.

\section{Závěr}

Cílem článku bylo představit specifika vyrovnání nemajetkové újmy při ublížení na zdraví ideálními výhodami. Úvodem byly předestřeny argumenty, na základě kterých se lze přiklonit k závěru, že i v oblasti ideálních výhod a nevýhod (zde v souvislosti se zdravím člověka) je vhodné pravidla teorie vyrovnání újmy prospěchem mutatis mutandis aplikovat. Vybraná rakouská a německá judikatura ukázala, jakým zpơsobem posuzují tyto př́ipady soudy, přičemž následoval doktrinární rozbor jednotlivých kritérií. Aplikace těchto kritérií byla následně demonstrována na specifických skupinách případů (Fallgruppen).

Z kazuistiky zřetelně vyplynuly inherentní znaky problematiky vyrovnání újmy prospěchem v oblasti nemajetkové újmy při ubližení na zdraví, stejně tak jako s tím související a poměrně logická názorová rozkolísanost posuzování jednotlivých případů.

I když lze stěží očekávat, že se v budoucnu vytvoří univerzální pravidlo, podle něhož by bylo možné tuto problematiku komplexně a jednotně obsáhnout, o což se doktrína marně pokoušela více jak sto let, poukazují jednotlivá nyní aplikovaná kritéria na přinejmenším jednu významnou skutečnost. A to, že si je třeba uvědomit, které všechny okolnosti daného př́padu jsou rozhodné, vypořádat se s nimi a dospět se zřetelem k nim $\mathrm{k}$ hodnotově vyváženému závěru, zda danou výhodu vůči nevýhodě v podobě újmy na zdraví zohlednit.

„Reichlich schwer fassbare Formeln und Begriffe wie ,Sinn und Zweck', ,Zumutbarkeit" und ,Billigkeit‘ prägen den Bereich der Vorteilsausgleichung." 123

123 „Jsou to těžko uchopitelné kategorie jako ,smysl a účel', ,primérenost“ a spravedlnost', které utvárí a formuji problematiku vyrovnáni újmy prospèchem. "PLETZER, R. Vorteilsausgleich beim Schmerzengeld? Juristische Blätter, 2007, roč. 129 , č. 7 , s. 417. 